\title{
Current understanding of the genomic, genetic, and molecular control of insect resistance in rice
}

\author{
Bo Du $\cdot$ Rongzhi Chen $\cdot$ Jianping Guo $•$ Guangcun He $\mathbb{C}$
}

Received: 19 June 2019 / Accepted: 19 January 2020 /Published online: 8 February 2020

(C) The Author(s) 2020

\begin{abstract}
Rice (Oryza sativa) is both a vital source of food and a key model cereal for genomic research. Insect pests are major factors constraining rice production. Here, we provide an overview of recent progress in functional genomics research and the genetic improvements of insect resistance in rice. To date, many insect resistance genes have been identified in rice, and 14 such genes have been cloned via a map-based cloning approach. The proteins encoded by these genes perceive the effectors of insect and activate the defense pathways, including the expression of defense-related genes, including mitogen-activated protein kinase, plant hormone, and transcription factors; and defense mechanism against insects, including callose deposition, trypsin proteinase inhibitors (TryPIs), secondary metabolites, and green leaf volatiles (GLVs). These ongoing functional genomic studies provide insights into the molecular basis of rice-insect interactions and facilitate the development of novel insect-resistant rice varieties, improving long-term control of insect pests in this crucial crop.
\end{abstract}

Keywords Functional genomics · Resistance to insect . Rice

This article is part of the Topical Collection on Rice Functional Genomics

B. Du $\cdot$ R. Chen $\cdot$ J. Guo $\cdot$ G. He $(\bowtie)$

State Key Laboratory of Hybrid Rice, Wuhan University,

Wuhan 430072, China

e-mail: gche@whu.edu.cn

\section{Introduction}

Insect pests pose severe constraints to agriculture and threaten food security worldwide (Oerke 2006). More than half a million insect species on Earth are estimated to obtain their nutrients from plants (Strong et al. 1984). Insect infestations are especially severe in rice, which grows in warm, humid environments. Rice plants provide an attractive and nutritious food source for many phytophagous insects. Hundreds of insect species damage rice to various degrees, but only $\sim 20$ species occur regularly and cause major damage to rice (Grist and Lever 1969). In China, the total area of rice infested by brown planthopper (BPH) was estimated at over 25 million hectares, resulting in a rice production loss of 2.7 million tons between 2005 and 2008 (Qiu et al. 2012; Hu et al. 2016a).

Insects feed on all parts of a rice plant during all stages of growth. Herbivorous insects have various feeding modes, but most of these insects can be classified into two groups: chewing insects and piercingand-sucking insects. Chewing insects, such as stem borers and leaf folders, have mouthparts that break off and ingest plant tissues, causing substantial mechanical damage. Insects with piercing-and-sucking feeding habits, including planthoppers and leafhoppers, have sharp, elongated mouthparts that penetrate plant cells and suck up nutrients from vascular tissues. Planthoppers and leafhoppers are also important vectors of plant disease agents, causing indirect damage to plants (Fujita et al. 2013). 
Insect outbreaks in rice are recorded in antiquity. The Book of Odes, a collection of 305 Chinese poems and songs from the 10th to the 7 th centuries $\mathrm{BC}$, mentions the damage in rice caused by the stem borer (He et al. 2013a). However, the severity and frequency of insect outbreaks have increased over the past several decades. Most modern rice varieties are grown with high fertilizer inputs and have a higher nutrient content, but reduced physical and chemical defenses compared with the wild relatives and landraces (Chen et al. 2015; Olsen and Wendel 2013). Crop losses caused by insects are expected to be further exacerbated by global warming, which increases the population growth and metabolic rates of insects (Deutsch et al. 2018).

Controlling insect pests is a key priority to secure rice productivity to feed the rapidly growing human population without ecological degradation (Crist et al. 2017). The main strategy for crop protection against insects over the past 50 years has been the application of chemical insecticides, but the use of such compounds is set to decline in China and other countries. Resistant rice cultivars are being sought as an effective integrated pest management tactic for rice production. A major objective of rice breeding programs is to incorporate insect resistance into modern cultivars (Zhang 2007). Insect resistance in plants involves a gene or suite of genes that produce a product or products that inactivate or otherwise disable the target insect. Resistant rice cultivars alter the physiology and behavior of insects, which in turn affects the insects' susceptibility to chemical and biological control mechanisms ( $\mathrm{Li}$ et al. 2014). Transgenic rice harboring an exogenous Bt gene (encoding an insecticidal toxin produced by Bacillus thuringiensis) has been used to breed insect-resistant rice. The Bt gene is effective against the stem-borer-and-leaf-folderchewing insects, but not against piercing-and-sucking insects, such as brown planthopper.

Over the past several decades, great progress has been made in the screening of insect-resistant rice germplasm, identifying resistance genes, and uncovering the molecular mechanisms of host resistance. The use of resistance genes and other efforts to breed "Green Super Rice", a high-yielding, good-quality, insect-resistant ideal rice variety, will increase the profitability of rice production and contribute to a healthy ecological environment. This review addresses research advances underpinning strategies to improve the resistance of rice to insect pests. We focus on the genetic and molecular mechanisms of insect resistance and the practical application of gene technologies to rice breeding for improved insect resistance, which represent the development trend of rice insect resistance breeding and also provide a reference for other crops.

\section{Functional genomics of insect resistance in rice}

Genetics studies of insect resistance

Many rice genomic resources, including cultivated and wild rice species, are available globally, providing an invaluable source of insect resistance in rice. One way to breed insect-resistant rice varieties is to transfer resistance genes identified in traditional rice varieties and wild rice into modern cultivars. The ease of such transfer, however, depends on how closely related the two species of rice are and the degree to which they have become reproductively isolated. Cultivated rice and wild rice species with AA genomes can be directly crossed to transfer insect resistance genes to modern cultivars (Brar and Khush 2006). Wild rice with other genomes (e.g., BB, CC, and BBCC) must instead be crossed with rice cultivars via hybrid embryo rescue (Huang et al. 2000).

The phenotypic selection followed by population construction is a traditional strategy used to study insect resistance in rice. By evaluating the phenotype of $F_{1}$ plants or the phenotypic segregation ratio of the $F_{2}$ population from a cross between a resistant and susceptible parent, one could determine whether insect resistance is controlled by dominant or recessive genes or by one or more major genes. In addition, by assessing the phenotypic segregation ratios of the $\mathrm{F}_{2}$ populations and $\mathrm{F}_{3}$ progenies of a cross between resistant cultivars, one could determine if resistance genes in different varieties are allelic, closely linked, or located on different chromosomes. Such studies have indicated that insect resistance in rice is controlled by major genes. Scientists at International Rice Research Institute (IRRI) have identified many planthopper and leafhopper resistance genes, including $\mathrm{BPH} 1$ to $\mathrm{BPH} 9$ from the rice varieties Mudgo, ASD7, Rathu Heenati, Babawee, ARC10550, Swarnalata, T12, Chin Saba, and Pokkali (Athwal et al. 1971, Laksminarayana and Khush 1977, Sidhu and Khush 1978, Khush et al. 1985, Kabir and Khush 1988, Nemoto et al. 1989); WBPH1 to WBPH5 from Nagina 22, ARC10239, ADR52, Podiwi A8, and N'Diang Marie (Sidhu et al. 1979; Angeles et al. 1981; 
Hernandez and Khush 1981; Wu and Khush 1985); and GLH1 to GLH5 from Pankhari 203, ASD7, IR8, PTB8, and ASD8, respectively (Athwal et al. 1971; Siwi and Khush 1977) (Table 1). These genes have been used in the breeding of resistant rice varieties (Khush and Virk 2005).

Insect resistance gene mapping

With the development of molecular markers technologies, many insect resistance genes and quantitative trait loci (QTLs) have been identified in rice and located on genetic linkage maps through the analysis of phenotypic and genotypic variation in different populations (Table 1).

Three species of planthoppers, brown planthopper (BPH), white-backed planthopper (WBPH), and small brown planthopper (SBPH), are the leading causes of yield losses in rice and cause economic damage globally (Backus et al. 2005). Since the BPH-resistance gene $B P H 1$ was first identified in 1971 (Athwal et al. 1971), over 34 such genes have been reported, including 20 (BPH1 to BPH9, BPH16, BPH17, bph19(t), bph25, BPH26, BPH27(t), BPH28, BPH30 to BPH33) in the traditional cultivated rice varieties, and others in wild rice species, including $\mathrm{BPH} 10$ and $\mathrm{BPH} 18$ from $O$. australiensis, bph11-15 from O. officinalis, BPH20, BPH21, and BPH23 from O. minuta, bph18(t), bph19(t), bph22 to BPH24(t), BPH27, bph29, BPH30 from $O$. rufipogon, $B P H 22(t)$ from $O$. glaberrima, and BPH34 from O. nivara (Table 1). Most BPH resistance genes have been mapped to particular chromosomal locations, except for $b p h 5, b p h 8, B P H 22(t)$ to $B P H 24(t)$ (Table 1), and 14 genes have been isolated via mapbased cloning.

BPH resistance genes are usually present in clusters on chromosomes 3, 4, 6, and 12 (Cheng et al. 2013b, Fig. 1). Eight of these genes (BPH1, bph2, bph 7, BPH9, BPH10, BPH18, BPH21, and BPH26) are clustered together in a 19.1-24.4 Mb region between markers RM7102 and B122 on chromosome 12L, whereas 12 genes are clustered in three regions on chromosome 4 (BPH30 and BPH33 in a 0.91-0.97 Mb region between markers H99 and H101; BPH3/17, BPH12, BPH15, $B P H 20(t)$, and $b p h 22(t)$ in a 4.1-8.9 Mb region between markers RM8212 and B44; and BPH6, bph18(t), BPH27, BPH27(t), and BPH34 in a $19.1-25.0 \mathrm{Mb}$ between markers RM16846 and RM6506). BPH3, bph4, bph 25, bph29, and BPH32 are present in a $0.2-1.7 \mathrm{Mb}$ region between markers S00310 and RM8101 on chromosome 6S, while BPH13 and bph19(t) are located on chromosome $3 \mathrm{~S}$, and bph11, BPH14, and BPH31 are located on chromosome 3L (Fig. 1).

In addition, QTLs have been detected in various rice chromosomes using different mapping populations from crosses between susceptible and resistant varieties. qBPH6(t) was mapped between markers RM469 and RM568 on chromosome 6 in IR71033-121-15 (Jairin et al. 2007a). $q B P H 3$ was identified in rice line IR02W101 and mapped between markers t6 and f3 on chromosome 3 (Hu et al. 2015b). Several QTLs have also been identified on chromosomes 4 , including $q B P H 4, q B P H 4.2, q B P H 4.3$, and qBPH4.4 from IR02W101, IR65482-17-511 and Salkathi, respectively (Hu et al. 2015a, b; Mohanty et al. 2017).

Twelve major genes and a number of QTLs associated with WBPH resistance have been identified to date, including WBPH1 to WBPH5, which were identified by traditional genetic analysis. However, only WBPH1 and WBPH2 were mapped on chromosomes 7 and 6, respectively (Sidhu et al. 1979; Liu et al. 2002). WBPH6 was identified in rice variety Guiyigu and mapped on chromosome $11 \mathrm{~S}$ (Li et al. 2004). WBPH7 and WBPH8, which were introgressed from $O$. officinalis, were mapped on chromosomes 3 and 4 in the same regions as the BPH14 and BPH15, respectively (Tan et al. 2004). Furthermore, four WBPH resistance genes in Sinna Sivappu, designated as wbph $9(t)$, wbph10(t), wbph11 $(t)$, and WBPH12(t), were mapped on chromosome $6,12,4$ by molecular markers, respectively (Ramesh et al. 2014). One gene $(O v c)$ and four QTLs (qOVA-1-3, qOVA-4, qOVA-5-1, and qOVA-5-2) that exhibit WBPH ovicidal activity were identified in the japonica rice variety Asominori and mapped on chromosomes 6, 1, 4, and 5, respectively (Yamasaki et al. 2003). The QTLs $q W L 6$ from cultivar Chunjiang 06 and $q W B P H 11$ from IR54751 were delimited into a $122 \mathrm{~kb}$ region between markers M3 and M5 on chromosome 6 and a $450 \mathrm{~kb}$ region between markers DJ53973 and SNP56 on chromosome 6, respectively (Yang et al. 2014; Fan et al. 2018).

Prior to 2009, there were few reports of SBPH resistance genes or QTLs. Subsequent screening efforts have revealed a number of rice accessions with SBPH resistance (Duan et al. 2009). Three QTLs related to SBPH resistance ( $q S B P H 2 b, q S B P H 3 d$, and $q S B P H 12 a$ ) were identified on chromosomes 2 , 3 , and 12 in the cultivar Mudgo, respectively (Duan 
Table 1 Insect resistance genes identified in rice

\begin{tabular}{|c|c|c|c|c|}
\hline Gene & Germplasm & Chromosome & Linked markers & References \\
\hline \multicolumn{5}{|c|}{ Brown planthopper } \\
\hline BPH1 & Mudgo & 12 & pBPH4-pBPH14 & Athwal et al. 1971, Cha et al. 2008 \\
\hline$b p h 2$ & ASD7 & 12 & RM7102-RM463 & Athwal et al. 1971, Sun et al. 2006 \\
\hline BPH3 & Rathu Heenati & 6 & RM589-RM588 & $\begin{array}{l}\text { Laksminarayana and Khush 1977, Jairin et al. } \\
\text { 2007b }\end{array}$ \\
\hline $\mathrm{BPH} 3$ & Rathu Heenati & 4 & RHD9-RHC10 & Liu et al. 2015 \\
\hline$b p h 4$ & Babawee & 6 & RM589-RM586 & Sidhu and Khush 1978, Jairin et al. 2010 \\
\hline bph5 & ARC 10550 & - & - & Khush et al. 1985 \\
\hline BPH6 & Swarnalata & 4 & $\mathrm{H}-\mathrm{Y9}$ & Kabir and Khush 1988, Guo et al. 2018 \\
\hline$b p h 7$ & $\mathrm{~T} 12$ & 12 & RM3448-RM313 & Kabir and Khush 1988, Qiu et al. 2014 \\
\hline bph 8 & Chin Saba & - & - & Nemoto et al. 1989 \\
\hline ВPH9 & Pokkali & 12 & InD2-RsaI & Nemoto et al. 1989, Zhao et al. 2016 \\
\hline ВPH10 & O.australiensis & 12 & RG457-CDO459 & Ishii et al. 1994 \\
\hline bph11 & O.officinalis & 3 & G1318 & Hirabayashi et al. 1998 \\
\hline BPH12 & B14 (O.officinalis) & 4 & RM16459-RM1305 & Qiu et al. 2012 \\
\hline ВРH13 & O.officinalis & 3 & RZ892-RG191 & Renganayaki et al. 2002 \\
\hline BPH14 & B5 (O.officinalis) & 3 & SM1-G1318 & Du et al. 2009 \\
\hline BPH15 & B5 (O.officinalis) & 4 & RG1-RG2 & Yang et al. 2004 \\
\hline BPH16 & M1635-7 & 12 & RM6732-R10289 & Hirabayashi et al. 2004 \\
\hline BPH17 & Rathu Heenati & 4 & RM8213-RM5953 & Sun et al. 2005 \\
\hline BPH18 & $\begin{array}{l}\text { IR65482-7-216-1-2 } \\
\quad(\text { O. australiensis })\end{array}$ & 12 & BIM3-BN162 & Ji et al. 2016 \\
\hline$b p h 18(t)$ & O. rufipogon & 4 & RM273-RM6506 & Li et al. 2006 \\
\hline $\operatorname{bph} 19(t)$ & AS20-1 & 3 & RM6308-RM3134 & Chen et al. 2006 \\
\hline $\operatorname{bph} 19(t)$ & O. rufipogon & 12 & RM17 & Li et al. 2006 \\
\hline$B P H 20(t)$ & IR71033-121-15 (O. miniuta) & 4 & B42-B44 & Rahman et al. 2009 \\
\hline$B P H 21(t)$ & IR71033-121-15 (O. miniuta) & 12 & S12094A-B122 & Rahman et al. 2009 \\
\hline$B P H 22(t)$ & O. glaberrima & - & - & Ram et al. 2010 \\
\hline$B P H 23(t)$ & O. minuta & - & - & Ram et al. 2010 \\
\hline $\operatorname{bph} 22(t)$ & O. rufipogon & 4 & RM8212-RM261 & Hou et al. 2011 \\
\hline $\operatorname{bph} 23(t)$ & O. rufipogon & 8 & RM2655-RM3572 & Hou et al. 2011 \\
\hline $\operatorname{bph} 24(t)$ & IR72678-6-9-B (O. rufipogon) & - & - & Deen et al. 2010 \\
\hline bph 25 & ADR52 & 6 & S00310-RM8101 & Myint et al. 2012 \\
\hline BPH26 & ADR52 & 12 & DS72B4-DS173B & Tamura et al. 2014 \\
\hline BPH27 & O. rufipogon & 4 & RM16846-RM16853 & Huang et al. 2013 \\
\hline$B P H 27(t)$ & Balamawee & 4 & Q52-Q20 & He et al. $2013 b$ \\
\hline$B P H 28(t)$ & DV85 & 11 & InDel55-InDel66 & Wu et al. 2014 \\
\hline $\operatorname{bph} 29$ & RBPH54 (O. rufipogon) & 6 & BYL8-BID2 & Wang et al. 2015b \\
\hline bph30 & RBPH54 (O. rufipogon) & 10 & RM222-RM244 & Yang et al. 2012 \\
\hline ВРН30 & AC-1613 & 4 & SSR28-SSR69 & Wang et al. 2018a \\
\hline ВРН31 & CR2711-76 & 3 & PA26-RM2334 & Prahalada et al. 2017 \\
\hline ВPH32 & РTB33 & 6 & RM19291-RM8072 & Ren et al. 2016 \\
\hline
\end{tabular}


Table 1 (continued)

\begin{tabular}{|c|c|c|c|c|}
\hline Gene & Germplasm & Chromosome & Linked markers & References \\
\hline ВРH33 & KOLAYAL & 4 & H99-H101 & Hu et al. 2018 \\
\hline ВРH34 & IRGC104646 (O. nivara) & 4 & RM16994-RM17007 & Kumar et al. 2018 \\
\hline$q B P H 3$ & IR02W101 (O.officinalis) & 3 & t6-f3 & Hu et al. $2015 b$ \\
\hline$q B P H 4$ & IR02W101 (O.officinalis) & 4 & P17-xc4-27 & Hu et al. $2015 b$ \\
\hline$q B P H 4.2$ & $\begin{array}{l}\text { IR65482-17-511 } \\
\quad(\text { O. australiensis })\end{array}$ & 4 & RM261-XC4-27 & Hu et al. $2015 \mathrm{a}$ \\
\hline$q B P H 4.3$ & Salkathi & 4 & RM551-RM335 & Mohanty et al. 2017 \\
\hline$q B P H 4.4$ & Salkathi & 4 & RM335-RM5633 & Mohanty et al. 2017 \\
\hline$q B P H 6(t)$ & IR71033-121-15 & 6 & RM469-RM568 & Jairin et al. 2007a \\
\hline \multicolumn{5}{|c|}{ White-backed planthopper } \\
\hline WBPH1 & Nagina 22 & 7 & - & Sidhu et al. 1979 \\
\hline WBPH2 & ARC10239 & 6 & RZ667 & Angeles et al. 1981, Liu et al. 2002 \\
\hline WBPH3 & ADR52 & - & - & Hernandez and Khush 1981 \\
\hline wbph4 & Podiwi A8 & - & - & Hernandez and Khush 1981 \\
\hline WBPH5 & N'Diang Marie & - & - & Wu and Khush 1985 \\
\hline WBPH6 & Guiyigu & 11 & RM167 & Li et al. 2004 \\
\hline WBPH7 & B5 (O.officinalis) & 3 & R1925-G1318 & Tan et al. 2004 \\
\hline WBPH8 & B5 (O.officinalis) & 4 & R288-S11182 & Tan et al. 2004 \\
\hline$w b p h 9(t)$ & Sinna Sivappu & 6 & RM589-RM539 & Ramesh et al. 2014 \\
\hline wbph10(t) & Sinna Sivappu & 12 & SSR12-17.2-RM28487 & Ramesh et al. 2014 \\
\hline wbph11(t) & Sinna Sivappu & 4 & Rm3643-rm1223 & Ramesh et al. 2014 \\
\hline$W B P H 12(t)$ & Sinna Sivappu & 4 & RM16592-RM16649 & Ramesh et al. 2014 \\
\hline$O v c$ & Asominori & 6 & R2373-C946 & Yamasaki et al. 2003 \\
\hline qOVA-1-3 & Asominori & 1 & XNpb346-C112 & Yamasaki et al. 2003 \\
\hline$q O V A-4$ & Asominori & 4 & R1854 & Yamasaki et al. 2003 \\
\hline$q O V A-5-1$ & Asominori & 5 & $\mathrm{XNpb251-R3313}$ & Yamasaki et al. 2003 \\
\hline$q O V A-5-2$ & Asominori & 5 & $\mathrm{C} 1268$ & Yamasaki et al. 2003 \\
\hline$q W P H 2$ & O. rufipogon & 2 & RM1285-RM555 & Chen et al. 2010 \\
\hline$q W B P H 5$ & O. rufipogon & 5 & RM3870-RZ70 & Chen et al. 2010 \\
\hline$q W B P H 9$ & O. rufipogon & 9 & RG451-RM245 & Chen et al. 2010 \\
\hline$q W L 6$ & Chunjiang 06 & 6 & M3-M5 & Yang et al. 2014 \\
\hline$q W B P H 3.2$ & IR54751 & 3 & InDel3-23-InDel3-26 & Fan et al. 2018 \\
\hline$q W B P H 11$ & IR54751 & 11 & DJ53973-SNP56 & Fan et al. 2018 \\
\hline \multicolumn{5}{|c|}{ Small brown planthopper } \\
\hline$q S B P H 2 b$ & Mudgo & 2 & RM29-RM5791 & Duan et al. 2009 \\
\hline$q S B P H 3 d$ & Mudgo & 3 & RM5442-RM3199 & Duan et al. 2009 \\
\hline$q S B P H 12 a$ & Mudgo & 12 & I12-17-RM3331 & Duan et al. 2009 \\
\hline$q S B P H 2$ & Kasalath & 2 & R712-R1843 & Duan et al. 2010 \\
\hline$q S B P H 3$ & Kasalath & 3 & C1135-C80 & Duan et al. 2010 \\
\hline qSBPH8 & Kasalath & 8 & R1943-C390 & Duan et al. 2010 \\
\hline$q S B P H 11$ & Kasalath & 11 & $\mathrm{G} 257-\mathrm{S} 2260$ & Duan et al. 2010 \\
\hline$q S B P H 2$ & $\mathrm{~N} 22$ & 2 & RM263-RM1385 & Wang et al. 2013b \\
\hline
\end{tabular}


Table 1 (continued)

\begin{tabular}{|c|c|c|c|c|}
\hline Gene & Germplasm & Chromosome & Linked markers & References \\
\hline$q S B P H 3$ & $\mathrm{~N} 22$ & 3 & RM22-RM545 & Wang et al. 2013b \\
\hline qSBPH5 & $\mathrm{N} 22$ & 5 & RM153-RM413 & Wang et al. $2013 \mathrm{~b}$ \\
\hline$q S B P H 7$ & $\mathrm{~N} 22$ & 7 & RM234-RM429 & Wang et al. 2013b \\
\hline$q S B P H 11$ & $\mathrm{~N} 22$ & 11 & RM209-RM21 & Wang et al. 2013b \\
\hline$q S B P H 3 d$ & Pf9279-4 (O. officinalis) & 3 & RM218-RM745 & Zhang et al. 2014 \\
\hline$q S B P H 7 a$ & Pf9279-4 (O. officinalis) & 7 & RM7012-RM6338 & Zhang et al. 2014 \\
\hline$q S B P H 12 b$ & Pf9279-4 (O. officinalis) & 12 & RM463-RM6256 & Zhang et al. 2014 \\
\hline$q S B P H 1$ & 9194 & 1 & RM3738-RM8236 & Sun et al. 2017 \\
\hline$q S B P H 5$ & 9194 & 5 & RM18452-RM163 & Sun et al. 2017 \\
\hline qSBPH8 & 9194 & 8 & RM210-RM3845 & Sun et al. 2017 \\
\hline qSBPH9 & 9194 & 9 & RM257-RM160 & Sun et al. 2017 \\
\hline$q S B P H 5$ & WR24 & 5 & Indel 5-11-RM3664 & Xu et al. $2018 b$ \\
\hline$q S B P H 7$ & WR24 & 7 & RM6403-RM234 & Xu et al. $2018 b$ \\
\hline qSBPH10 & WR24 & 10 & RM25664-RM228 & $\mathrm{Xu}$ et al. $2018 \mathrm{~b}$ \\
\hline \multicolumn{5}{|l|}{ Gall midge } \\
\hline GM1 & W1263 & 9 & RM444-RM219 & Biradar et al. 2004 \\
\hline$G M 2$ & Phalguna & 4 & RM241-RM317 & Himabindu et al. 2007 \\
\hline gm3 & RP2068-18-3-5 & 4 & RM17480-gm3SSR4 & Sama et al. 2014 \\
\hline GM4 & Abhaya & 8 & RM22551-RM22562 & Divya et al. 2015 \\
\hline GM5 & ARC5984 & 12 & RM101-RM309 & Dubey and Chandel 2010 \\
\hline GM6 & Duokang \#1 & 4 & RG214-RG476 & Katiyar et al. 2001 \\
\hline GM7 & RP2333-156-8 & 4 & F8LB-SA598 & Sardesai et al. 2002 \\
\hline GM8 & Aganni & 8 & RM22685-RM22709 & Divya et al. 2018 \\
\hline GM9 & Line9 & & & Shrivastava et al. 2003 \\
\hline GM10 & BG 380-2 & & & Kumar et al. 2005 \\
\hline GM11 & CR57-MR1523 & 12 & RM28574-RM28706 & Himabindu et al. 2010 \\
\hline \multicolumn{5}{|c|}{ Green rice leafhopper } \\
\hline GRHI & IR24 & 5 & R569-C309 & Kadowaki et al. 2003 \\
\hline GRH2 & DV85 & 11 & $\mathrm{R} 2458-\mathrm{C} 50$ & Kadowaki et al. 2003 \\
\hline GRH3 & Rantaj emas 2 & 6 & C288B-C133A & Saka et al. 2006 \\
\hline GRH4 & DV85 & 3 & C1186-R2982 & Kadowaki et al. 2003 \\
\hline GRH5 & W1962 (O. rufipogon) & 8 & RM3754-RM3761 & Fujita et al. 2006 \\
\hline GRH6 & SML17, IRGC105715 & 4 & RM8213-C708 & Fujita et al. 2004, Tamura et al. 2004 \\
\hline$q G R H 9$ & IRGC104038 (O. glaberrima) & 9 & RM215-RM2482 & Fujita et al. 2010a \\
\hline \multicolumn{5}{|c|}{ Green leafhopper } \\
\hline$G L H 1$ & Pankahari 203 & 5 & - & Athwal et al. 1971 \\
\hline GLH 2 & ASD7 & 11 & - & Athwal et al. 1971 \\
\hline GLH 3 & IR8 & 6 & - & Athwal et al. 1971 \\
\hline $\operatorname{glh} 4$ & PTB8 & 3 & - & Siwi and Khush 1977 \\
\hline GLH 5 & ASD8 & 8 & - & Siwi and Khush 1977 \\
\hline GLH 6 & TAPL 796 & 5 & - & Rezaul Karim and Pathak 1982 \\
\hline GLH 7 & Maddani Karuppan & - & - & Rezaul Karim and Pathak 1982 \\
\hline
\end{tabular}


Table 1 (continued)

\begin{tabular}{lllll}
\hline Gene & Germplasm & Chromosome & Linked markers & References \\
\hline glh8 & DV85 & - & - & Ghani and Khush 1998 \\
GLH 9 & IR28 & - & - & Angeles and Khush 1999 \\
glh10 & IR36 & - & - & Angeles and Khush 2000a \\
GLH 11 & IR20965-11-3-3 & - & - & Angeles and Khush 2000a \\
GLH 12 & ARC10313 & - & - & Angeles and Khush 2000b \\
GLH 13 & Asmaita & - & - & Angeles and Khush 2000b \\
GLH 14 & ARC11554 & 4 & Y3635-RZ262 & Sebastian et al. 1996 \\
Rice leaffolder & & & \\
$q R L F-1$ & Taichung Native 1 & 1 & RM3412-RM6716 & Rao et al. 2010 \\
$q R L F-2$ & Taichung Native 1 & 2 & RM207-RM48 & Rao et al. 2010 \\
$q R L F-3$ & Chuanjiang 06 & 3 & RM1022-RM7 & Rao et al. 2010 \\
$q R L F-4$ & Chuanjiang 06 & 4 & RM3276-RM255 & Rao et al. 2010 \\
$q R L F-8$ & Chuanjiang 06 & 8 & RM72-RM331 & Rao et al. 2010 \\
\hline
\end{tabular}

et al. 2009). Additional QTLs for SBPH resistance were identified, including qSBPH2, qSBPH3, $q S B P H 8$, and $q S B P H 11$ on chromosome $2,3,8$, and 11 in Kasalath, respectively; qSBPH2, qSBPH3, $q S B P H 5, q S B P H 7$, and $q S B P H 11$ on chromosome $2,3,5,7$, and 11 in N22, respectively; $q S B P H 3 d$, $q S B P H 7 a$, and $q S B P H 12 b$ on chromosome 3,7 , and 12 in Pf9279-4, respectively; qSBPH1, qSBPH5, $q S B P H 8$, and $q S B P H 9$ on chromosome $1,5,8$, and 9 in 9194, respectively; and $q S B P H 5, q S B P H 7$, and qSBPH10 on chromosome 5, 7, and 10 in WR24, respectively (Duan et al. 2010, Wang et al. 2013b, Zhang et al. 2014, Sun et al. 2017, Xu et al. 2018b, Table 1). Although individual QTLs have only small effects on SBPH resistance, it is useful to apply multiple QTLs for SBPH resistance breeding.
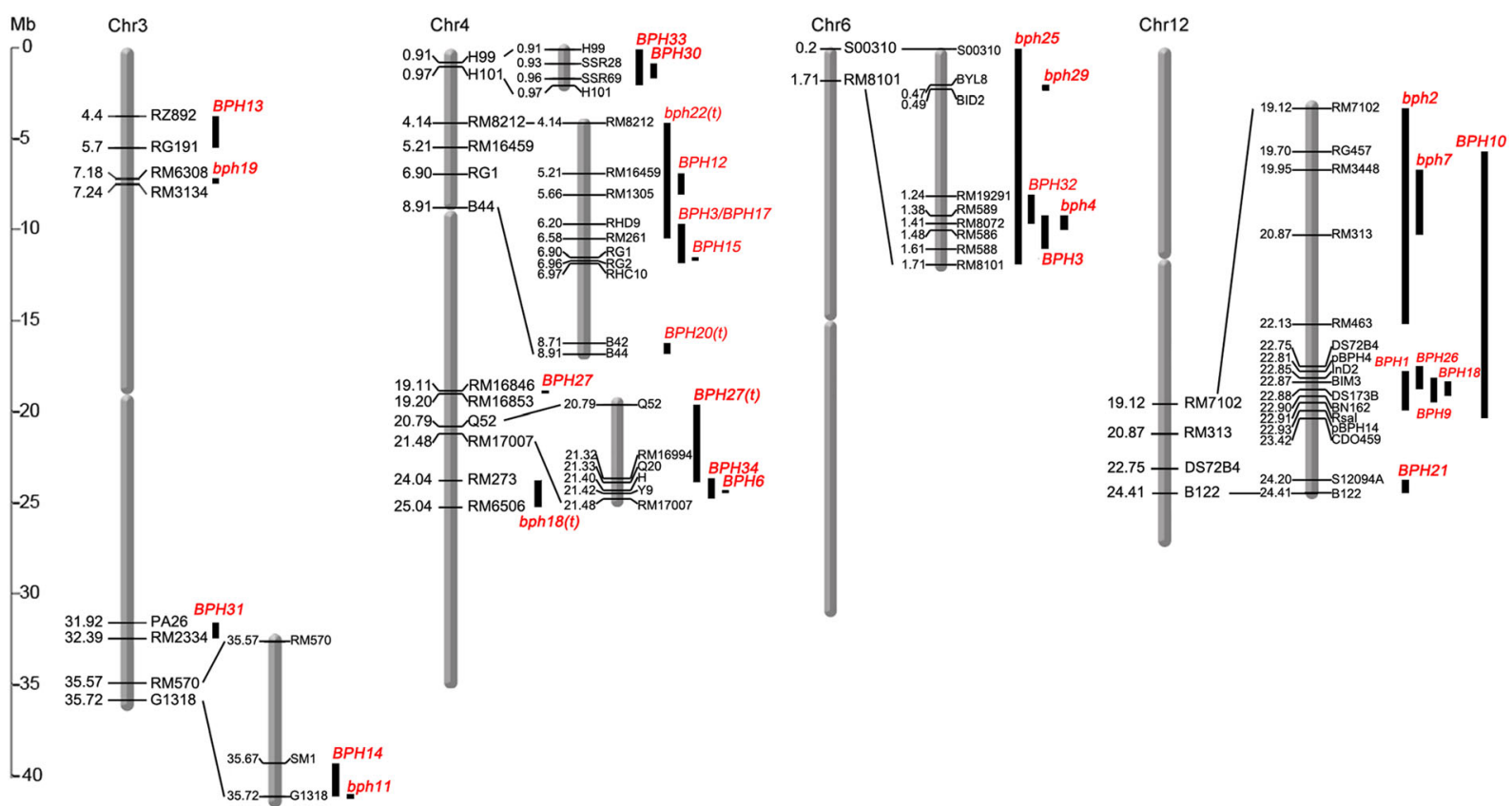

Fig. 1 Cluster of loci for BPH resistance genes on rice chromosomes. Numbers represent the physical distance on the left. Marker names are shown on the right. The black bars indicate the locations of BPH resistance genes 
Several sources of gall midge resistance have been characterized, including 11 genes associated with Asian rice gall midge biotype resistance; all of these genes except for GM9 and GM10 have been mapped (Yasala et al. 2012). GM1 from cultivar W1263 and GM5 from ARC5984 were mapped on chromosome 9 between markers RM444 and RM219 and on chromosome 12 between markers RM101 and RM309, respectively (Biradar et al. 2004; Dubey and Chandel 2010). Four genes (GM2, gm3, GM6, and GM7) are clustered in a $0.82 \mathrm{Mb}$ region between markers RM241 and RG476 on chromosome 4L, while GM4 and GM8 are present on chromosome $8 \mathrm{~S}$ in a $3.90 \mathrm{Mb}$ region between markers RM22551 and RM22709 (Yasala et al. 2012). Potential candidate genes associated with gm3, GM4, and GM8 have recently been identified. $g m 3$ was mapped to a $560 \mathrm{~kb}$ region in RP2068-18-3-5 and a gene encoding an NB-ARC protein was tentatively linked to gall midge resistance (Sama et al. 2014). GM4 from Abhaya was finely mapped to a $300 \mathrm{~kb}$ region; this region includes a candidate gene encoding a leucine-rich repeat (LRR) protein (Divya et al. 2015). GM8 from the indica rice variety Aganni was mapped to a $430 \mathrm{~kb}$ region containing a gene encoding a proline-rich protein (Divya et al. 2018). Complementation tests, however, have not been performed to verify these gall midge resistance genes.

Two species of leafhoppers, green rice leafhopper (GRH) and green leafhopper (GLH), are the common pests of cultivated rice pest species in Asia (Ghauri 1971; Angeles and Khush 2000a). Seven major genes governing GRH resistance have been identified and mapped to date, including GRH1 on chromosome 5 in IR24, GRH2 on chromosome 11 in DV85, GRH3 on chromosome 6 in Rantaj emas 2, GRH4 on chromosome 3 in DV85, GRH5 on chromosome 8 in W1962 (O. rufipogon), GRH6 on chromosome 4 in SML17 and IRGC105715, and $q G R H 9$ on chromosome 9 in IRGC104038 (O. glaberrima), respectively (Table 1). Eleven dominant and three recessive GLH resistance genes have been identified across resistant varieties, including GLH1 on chromosome 5 in Pankhari 203, GLH2 on chromosome 11 in ASD7, GLH3 on chromosome 6 in IR8, glh4 on chromosome 3 in PTB8, GLH5 on chromosome 8 in ASD8 and O. rufipogon, and GLH6 on chromosome 5 in TAPL796 (Table 1). Only GLH14 has been located on chromosome 4 using molecular markers Y3635 and RZ262 in ARC11554 (Sebastian et al. 1996).
Thus far, no stem borer resistance genes have been identified, although resistant wild and cultivated rice materials have been reported. A study using a doubled haploid population of CJ06/TN1 uncovered five QTLs for rice leaffolder (RLF) resistance on chromosomes 1 , $2,3,4$, and 8 . The effect of a single locus is limited, but QTLs pyramiding markedly improved leaffolder resistance in rice (Rao et al. 2010).

In summary, several insect resistance genes have been identified in rice, most of which are clustered on chromosomes 3, 4, 6, 8, and 12 in rice (Table 1, Fig. 1). These clustered genes might represent closely linked genes, different alleles of the same gene, or the same gene responding to different insects. Eight BPH resistance genes are clustered on chromosome 12L. These eight genes were isolated and shown to be the alleles of the same gene (Zhao et al. 2016). Such allelic variation of a single resistance gene confers resistance to different BPH biotypes.

Cloning and characterization of insect resistance genes in rice

There is a pressing need to clone and characterize insect resistance genes. Such genes would facilitate the breeding of durable, broad-spectrum insect-resistant rice cultivars and the analysis of molecular mechanisms underlying plant resistance to insects. In the past decade, much progress has been made in isolating insect resistance genes in rice. Several BPH resistance genes have been cloned and characterized by map-based cloning, shedding light on the molecular mechanisms of insect resistance in a plant (Table 2).

BPH14 was the first BPH resistance gene cloned through map-based cloning (Du et al. 2009). This gene was initially identified on chromosome $3 \mathrm{~L}$ in $\mathrm{B} 5$ rice, an introgression line derived from the wild rice species $O$. officinalis (Huang et al. 2001). Through high-resolution mapping, $\mathrm{BPH} 14$ was localized to a $34 \mathrm{~kb}$ region containing two candidate resistance genes, $R a$ and $R b$. Further transgene research revealed that only transgenic lines expressing $R a$ were BPH resistant, identifying this as the BPH14 gene. BPH14 encodes a CC-NB-LRR (coiled-coil, nucleotide-binding, and leucine-rich repeat) protein that is a typical NLR family member, revealing the similarities between insect and disease resistance in plants. $B P H 14$, which is primarily expressed in vascular bundles, activates salicylic acid (SA) signaling and induces callose deposition on rice 
Table 2 Insect resistance genes cloned in rice

\begin{tabular}{|c|c|c|c|c|c|c|c|}
\hline Gene & Germplasm & Chr. & Encoded protein & $\begin{array}{l}\text { Subcellular } \\
\text { localization }\end{array}$ & Expression pattern & $\begin{array}{l}\text { Resistance } \\
\text { against }\end{array}$ & References \\
\hline BPH1 & Mudgo & 12 & CC-NB-NB-LRR & $\begin{array}{l}\text { Endomembrane } \\
\text { system }\end{array}$ & Vascular bundle & $\mathrm{BPH}$ & $\begin{array}{l}\text { Zhao et al. } \\
\quad 2016\end{array}$ \\
\hline bph2 & ASD7 & 12 & CC-NB-NB-LRR & $\begin{array}{l}\text { Endomembrane } \\
\text { system }\end{array}$ & Vascular bundle & $\mathrm{BPH}$ & $\begin{array}{l}\text { Tamura et al. } \\
2014\end{array}$ \\
\hline ВPH3 & Rathu Heenati & 4 & $\begin{array}{l}\text { Lectin receptor } \\
\text { kinases }\end{array}$ & Plasma membrane & Vascular bundle & $\begin{array}{l}\text { BPH and } \\
\text { WBPH }\end{array}$ & Liu et al. 2015 \\
\hline BPH6 & Swarnalata & 4 & Atypical LRR & Exocyst & $\begin{array}{l}\text { Vascular } \\
\text { bundle/sclerenchyma }\end{array}$ & $\begin{array}{l}\mathrm{BPH} \text { and } \\
\mathrm{WBPH}\end{array}$ & $\begin{array}{l}\text { Guo et al. } \\
2018\end{array}$ \\
\hline$b p h 7$ & $\mathrm{~T} 12$ & 12 & CC-NB-NB-LRR & $\begin{array}{l}\text { Endomembrane } \\
\text { system }\end{array}$ & Vascular bundle & $\mathrm{BPH}$ & $\begin{array}{l}\text { Zhao et al. } \\
2016\end{array}$ \\
\hline ВPH9 & Pokkali & 12 & CC-NB-NB-LRR & $\begin{array}{l}\text { Endomembrane } \\
\text { system }\end{array}$ & Vascular bundle & $\mathrm{BPH}$ & $\begin{array}{l}\text { Zhao et al. } \\
\quad 2016\end{array}$ \\
\hline ВPH10 & IR65482-4-136-2-2 & 12 & CC-NB-NB-LRR & $\begin{array}{l}\text { Endomembrane } \\
\text { system }\end{array}$ & Vascular bundle & $\mathrm{BPH}$ & $\begin{array}{l}\text { Zhao et al. } \\
2016\end{array}$ \\
\hline BPH14 & B5 & 3 & CC-NB-LRR & $\begin{array}{l}\text { Nucleus and } \\
\text { cytoplasm }\end{array}$ & Vascular bundle & $\mathrm{BPH}$ & Du et al. 2009 \\
\hline BPH15 & B5 & 4 & $\begin{array}{l}\text { Lectin receptor } \\
\text { kinase }\end{array}$ & Plasma membrane & Vascular bundle & $\mathrm{BPH}$ & $\begin{array}{l}\text { Cheng et al. } \\
\text { 2013a }\end{array}$ \\
\hline BPH18 & IR65482-7-216-1-2 & 12 & CC-NB-NB-LRR & $\begin{array}{l}\text { Endomembrane } \\
\text { system }\end{array}$ & Vascular bundle & $\mathrm{BPH}$ & Ji et al. 2016 \\
\hline ВРН21 & IR71033-121-15 & 12 & CC-NB-NB-LRR & $\begin{array}{l}\text { Endomembrane } \\
\text { system }\end{array}$ & Vascular bundle & $\mathrm{BPH}$ & $\begin{array}{l}\text { Zhao et al. } \\
2016\end{array}$ \\
\hline BPH26 & ADR52 & 12 & CC-NB-NB-LRR & $\begin{array}{l}\text { Endomembrane } \\
\text { system }\end{array}$ & Vascular bundle & $\mathrm{BPH}$ & $\begin{array}{l}\text { Tamura et al. } \\
2014\end{array}$ \\
\hline $\operatorname{bph} 29$ & RBPH54 & 6 & $\begin{array}{l}\text { B3 DNA-binding } \\
\text { domain }\end{array}$ & Nucleus & Vascular bundles & $\mathrm{BPH}$ & $\begin{array}{l}\text { Wang et al. } \\
2015 b\end{array}$ \\
\hline ВРН32 & PTB33 & 6 & $\begin{array}{l}\text { Unknown SCR } \\
\text { domain }\end{array}$ & Plasma membrane & Vascular bundles & $\mathrm{BPH}$ & Ren et al. 2016 \\
\hline
\end{tabular}

CC-NB-LRR, coiled-coil nucleotide-binding, and leucine-rich repeat; SCR, short consensus repeat

sieve tubes, thereby impairing the feeding, development, and survival of BPH insects (Du et al. 2009). Recent research found that the BPH14 proteins form homocomplexes, which interact with WRKY46 and WRKY72, increasing their abundance to activate defensive genes in rice (Hu et al. 2017).

Several BPH resistance genes also encode NLR proteins. Previously, eight BPH resistance genes have been identified on chromosome 12L (Fig. 1). The cloning of BPH26 revealed that this gene also encodes a CC-NBLRR protein. $B P H 26$ shares an identical DNA sequence with $b p h 2$ and has a similar effect on the feeding of a bph2-virulent BPH biotype (Tamura et al. 2014). BPH18 localizes to the same locus as BPH26, which was confirmed via map-based cloning and complementation tests. $B P H 18$ encodes a CC-NB-NB-LRR protein containing two NB domains (Ji et al. 2016). BPH9 and its alleles $B P H 1, b p h 7, B P H 10$, and $B P H 21$ were cloned in 2016(Zhao et al. 2016). Finally, Bph9 and its alleles $B P H 1, b p h 7, B P H 10$, and $B P H 21$ were all cloned in 2016 (Zhao et al. 2016). BPH9 also encode a CC-NBNB-LRR protein that localizes to the endomembrane system. BPH9 confers both antixenosis and antibiosis to BPH. These eight BPH resistance genes, including the widely used $B P H 1$, are clustered on chromosome $12 \mathrm{~L}$ and are all allelic variants that can be classified into four allelotypes conferring different degrees of BPH resistance to different $\mathrm{BPH}$ biotypes (Zhao et al. 2016). A novel BPH resistance gene $B P H 6$ was recently cloned. This gene was previously mapped on chromosome 4L between the SSR markers Y9 and Y19 (Qiu et al. 2010). BPH6 encodes an atypical LRR protein that is localized to the exocyst, where it interacts with exocyst subunit OsEXO70E1. BPH6 expression 
facilitates exocytosis and cell wall reinforcement and induces coordinated SA, cytokinin (CK), and jasmonic acid (JA) signaling. This gene confers substantial resistance to all assessed WBPH and BPH biotypes without adversely affecting rice yields (Guo et al. 2018).

Two BPH resistance genes encode plasma membrane-localized lectin receptor-like kinases (LecRKs). The first gene, $B P H 15$ was initially mapped between C820 and S11182 on chromosome 4S, which confers more robust and stable resistance than that yielded by BPH14 (Huang et al. 2001). Through additional mapping efforts, $\mathrm{BPH} 15$ was subsequently localized into a $47 \mathrm{~kb}$ region between markers RG1 and RG2 (Yang et al. 2004), from which the lectin receptor kinase gene, OsLecRK, was cloned (Cheng et al. 2013a). OsLecRK functions in both innate immunity and seed germination in plant. Knocking down OsLecRK significantly reduced the resistance of rice plants to BPH (Cheng et al. 2013a). The second gene, BPH3, is a $\mathrm{BPH}$ resistance locus that was identified in Rathu Heenati (RH) rice more than 40 years ago (Laksminarayana and Khush 1977). BPH3 was first mapped on chromosome $6 \mathrm{~S}$ between markers RM19291 and RM8072 (Jairin et al. 2007b). Liu et al. (2015) cloned $B P H 3$ on chromosome 4 in RH, which was originally reported as $B P H 17$ (Hu et al. 2016a). By the crossing of 02428 and $\mathrm{RH}$ to generate the $\mathrm{BC}_{2} \mathrm{~F}_{2}$ and $\mathrm{BC}_{3} \mathrm{~F}_{2}$ populations, $B P H 3$ was mapped to a $79 \mathrm{~kb}$ region. Map-based cloning and functional characterization showed that $B P H 3$ is actually a cluster of three genes encoding the plasma membrane-localized proteins, lectin receptor kinases (OsLecRK1, OsLecRK2, and OsLecRK3). Plants co-expressing all three genes exhibited significantly enhanced, broad-spectrum resistance to BPH and WBPH (Liu et al. 2015).

Based on our knowledge of these BPH resistance genes, together with recently isolated aphid resistance genes in other crops (Kaloshian and Walling 2016)), it is very likely that plant immunity is the major mechanism underlying insect resistance. There is a commonality between plant defenses responses to parasitic pathogens and insects. BPH3 and BPH15 encode the plasma membrane-localized proteins that function as the first layer of rice immune system for insect. These genes encode the initial pattern recognition receptors (PRRs) that are activated in response to conserved herbivoryassociated molecular patterns (HAMPs) (Jing et al. 2017, Fig. 2). BPH6, BPH14, BPH9, and their alleles encode intracellular-localized NLR proteins, which perceive the effectors delivered to rice cells by $\mathrm{BPH}$ insects and trigger defenses responses (Cheng et al. 2013b, Jing et al. 2017, Fig. 2).

Nevertheless, two BPH resistance genes have been isolated that do not appear to be included in this immune system. bph29 is a recessive BPH resistance gene that was first identified in the wild rice species $O$. rufipogon. bph29 encodes a protein with a B3 DNA-binding domain (Wang et al. 2015b). The second gene, BPH32, was mapped on chromosome $6 \mathrm{~S}$ in rice variety PTB33. Bioinformatics and functional analyses showed that BPH32 encodes an SCR (short consensus repeat) domain-containing protein (Ren et al. 2016). The diversity of BPH resistance genes increases opportunities for the sustainable control of this insect.

\section{Molecular understanding of insect resistance}

Plant resistance to insects involves both constitutive defense and induced defense response. Constitutive defenses responses include the information of physical and chemical barriers prior to insect attack, whereas induced defenses responses include monitoring, signal transduction, and the production of defensive chemicals that are activated by insect attack (Chen 2008; Yang and Zhang 2016). Most insect resistance genes isolated to date encode plasma membrane-localized receptors and intracellular-localized receptors, indicating that induced defense and plant immunity play central roles in plant resistance to insects. Therefore, plant immunity against insects is similar to that against pathogens. In the past decade, much progress has been made in identifying insect elicitors and effectors as well as plant signaling transduction pathways, providing important insights into the molecular mechanism of insect resistance.

\section{Insect elicitors and effectors}

As insects feed or oviposit on plants, they inevitably release oral secretions (saliva, gut regurgitant) and oviposition fluids into the plant, which play an important role in plant-insect interactions (Miles 1999). Insect saliva has a number of properties and functions that are essential for successful feeding. Compounds in insect saliva may elicit or inhibit plant immune responses to insect attack (Miles 1999). Various elicitors have been identified in the oral secretion of insects, including $\beta$ glucosidase, fatty acid-amino acid conjugates (FACs), 


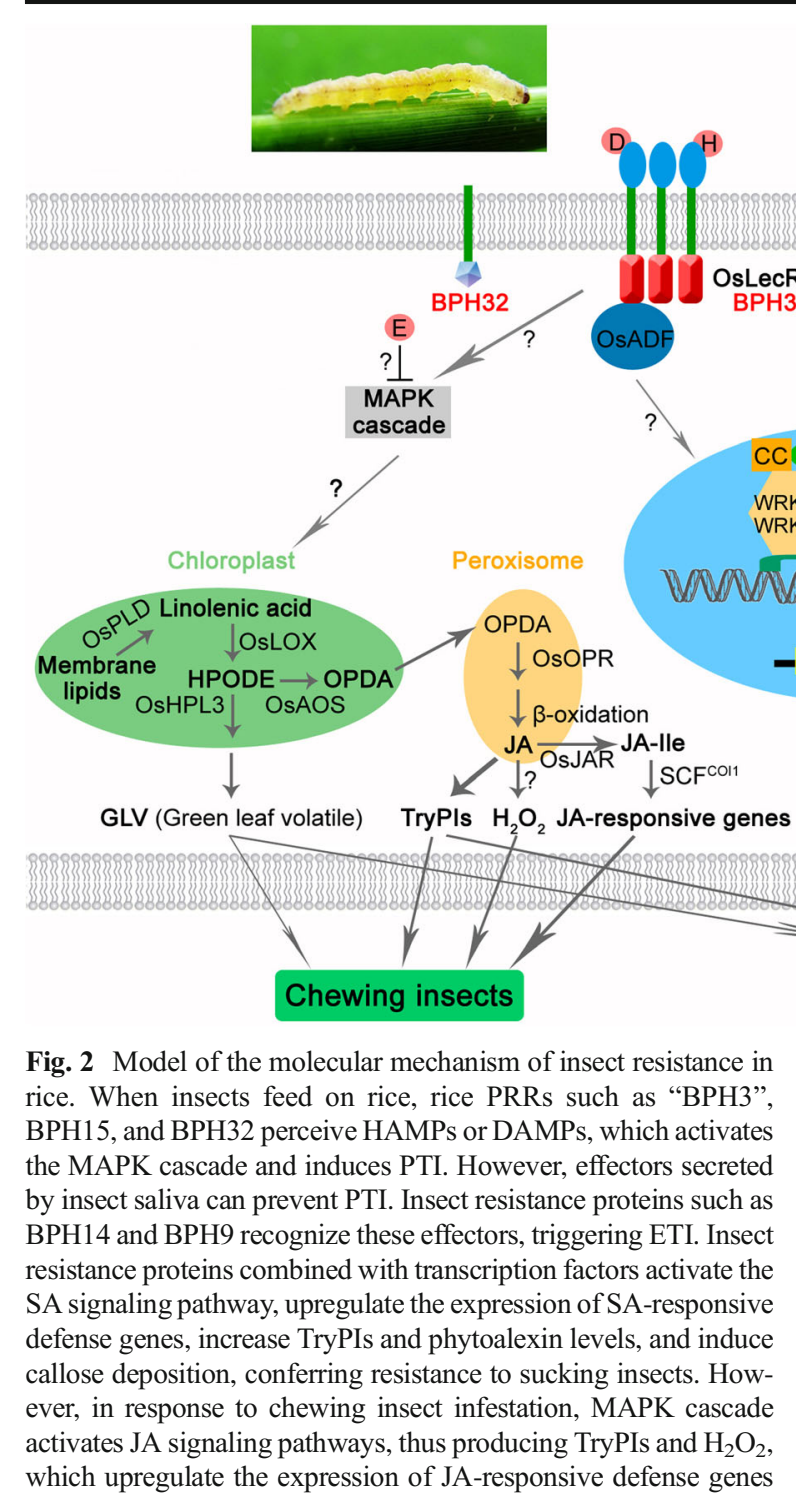

volicitin and caeliferins. These compounds activate the JA signaling pathway, leading to defenses responses against insects (Mattiacci et al. 1995; Alborn et al. 2007; Aggarwal et al. 2014). When mechanical wounds in rice were treated with oral secretions from lawn armyworms, JA and JA-Ile levels increased rapidly, suggesting that insect elicitors were actively perceived by the plant, although the elicitors that caused this response have not yet been identified (Fukumoto et al. 2013). Shinya et al. (2016) isolated the oral secretions from Mythimna loreyi, a chewing insect, and identified FAC. Although FAC alone had negligible elicitor activity in rice, it promoted the activity of the high molecular mass fraction, resulting in the accumulation of reactive oxygen species and metabolite.

Recent studies on the transcriptome, proteome, and secretome of insect salivary glands have sought to uncover the roles of salivary proteins in interactions between insects and plants (Hattori et al. 2015; Li et al. 2016; Huang et al. 2018; Rao et al. 2019). Transcriptome analysis of the aphid salivary gland identified the salivary protein $\mathrm{C} 002$, which functions in plants (Mutti et al. 2008). When BPH feed on rice, the salivary endo- $\beta$-1,4-glucanase NIEG1 is delivered into the plant to degrade celluloses in the plant cell walls, which helps the BPH's stylets to reach the phloem (Ji et al. 2017). 
The salivary gland-specific protein NcSP75 of GRH is also essential for establishing compatible interactions with rice plants (Matsumoto and Hattori 2018). Shangguan et al. (2018) characterized the BPH mucinlike protein (NIMLP), a salivary sheath component that is secreted into rice plants during feeding. NIMLP induces cell death, defense-related gene expression, and callose deposition in plants. BPH fed on $M L P$-dsRNA transgenic plants displayed mortality, reduced body size, and delayed maturation, suggesting that the MLPsilencing strategy could be used to control BPH. The DNase II protein in SBPH saliva was recently shown to degrade extracellular DNAs that acts as dangerassociated molecular patterns (DAMPs), and to prevent rice cells from detecting these DAMPs, and thereby suppressing the defense system in rice (Huang et al. 2019). Rao et al. (2019) established a BPH secretome composed of 1140 conserved or rapidly evolving salivary proteins. Through transient expression of $64 \mathrm{BPH}$ salivary proteins in plants, six proteins were shown to elicit defense responses. Finally, bacteria in BPH honeydew were recently shown to activate rice defenses response in rice, including the accumulation of phytoalexins and the release of volatile compounds to attract natural enemies of BPH (Wari et al. 2019). Together, these studies revealed that a variety of salivary proteins evoke defense responses in plant cells.

However, few insect-derived effectors that are recognized by plant receptors have been identified. Several researchers have attempted to map and clone insect avirulence genes using genetic crosses for effector identification. Jing et al. $(2012,2014)$ developed ESTSSR markers and constructed a highly comprehensive BPH linkage map with $96.6 \%$ coverage. Three major QTLs were mapped that control BPH preference or insect growth rates on resistant rice plants carrying $B P H 1$. Another gene, the recessive gene $v B P H 1$, controls BPH virulence on $\mathrm{BPH1}$ plants; this gene is located in the 10th linkage group (Kobayashi et al. 2014). In a study aimed at isolating an avirulence gene in Hessian fly (HF), the $v H 13$ gene was identified by highresolution mapping and association analysis; this gene enabled HF larvae to survive in wheat plants carrying the $H 13$ resistance gene. The $v H 13$ gene encodes a novel small modular protein (Aggarwal et al. 2014). Analysis of the HF genome suggested that SSGP-71 is likely the largest gene family in the effector reservoir. Mutations in different SSGP-71 genes help the wheat pest Mayetiola destructor avoid ETI directed by resistance genes $H 6$ and $H 9$ in wheat (Zhao et al. 2015). Although a number of putative elicitors and effectors have been identified in herbivorous insects and many insect resistance genes have been cloned in rice and other plants, the mechanisms used by plants to recognize these insect molecules and trigger resistance remain to be characterized.

Resistance-associated signal transduction in rice

Various approaches have been employed to explore the responses of rice to insect feeding, including suppression subtractive hybridization, cDNA array analysis, and transcriptomic and proteomic approaches, offering important insights into the mechanisms of insect resistance (Zhang et al. 2004; Wang et al. 2005; Yuan et al. 2005; Hua et al. 2007; Wang et al. 2008; Wei et al. 2009; Zhou et al. 2011; Wu et al. 2017).

MAPK signaling, a universal process in eukaryotes, serves as a bridge between a variety of stimuli and the expression of specific downstream defense genes in the plant innate immune system (Hettenhausen et al. 2015). MAPK signaling hss important roles in insect resistance in rice through the modulation of SA, JA, and ET signaling (Yuan et al. 2005, Wang et al. 2008). OsMPK3/4 positively regulate striped stem borer (SSB) resistance in rice by mediating SA and JA signaling. This process induces TrypPIs but has no effect on BPH resistance (Wang et al. 2013a; Liu et al. 2018). By contrast, OsMPK5/12 increase BPH resistance in rice by mediating the direct phosphorylation of OsERF1 and OsEREBP; these transcription factors regulate defense-related gene expression in the context of Bphi008-associated resistance (Hu et al. 2011). Recently, OsMAPK20-5, a group D MAPK gene, was identified in rice. This gene is rapidly induced by female BPH adults, but not by nymphs. OSMAPK20-5-silenced rice exhibited increased resistance to $\mathrm{BPH}$ adults and oviposited eggs and showed broad-spectrum resistance to BPH and WBPH in the field (Li et al. 2019).

Phytohormones are essential for controlling defense signaling in plants (Pieterse et al. 2012). Following BPH feeding, SA synthesis-related gene expression and SA levels increased in rice plants carrying the $B P H 14$, bph29, or BPH9 and its alleles compared to $\mathrm{BPH}-$ susceptible plants without any corresponding differences in JA synthesis-related gene expression or JA levels (Du et al. 2009; Wang et al. 2015b; Zhao et al. 2016). Similar findings have been reported in the 
context of SBPH-rice interactions, with SBPH infestations leading to the much more rapid induction of SA synthesis-related genes in resistant vs. susceptible rice cultivars, along with a corresponding decrease in JA synthesis-related genes expression (Duan et al. 2014). These findings suggest that the activation of SAdependent systemic acquired resistance occurs in plants as a protective mechanism against phloem-feeding insects, whereas such resistance mechanisms are JA independent.

JA is a critical mediator of plant defenses responses against chewing insects (McConn et al. 1997). JA signaling-associated gene expression is activated by SSB feeding in rice (Sun et al. 2010). In rice, JA biosynthesis and signal transduction are controlled by genes including OsPLD, OsLOX, OsAOS, and OsCOI1 (Lyons et al. 2013). Silencing these genes reduced the levels of JA and TrypPI, thus improving rice leaffolder and SBB larval performance while simultaneously increasing levels of SA and $\mathrm{H}_{2} \mathrm{O}_{2}$ levels to enhance (or at least not adversely affect) BPH resistance (Zhou et al. 2009; Qi et al. 2011; Ye et al. 2012; Zhou et al. 2014). JA also protects rice roots from two root-feeding insects and positively regulates plant resistance to root pests $(\mathrm{Lu}$ et al. 2015). Thus, JA and SA play distinct roles in mediating the defenses responses of rice against chewing and phloem-feeding insects.

The classic binary model of JA and SA defense mechanisms indicates that these phytohormones play opposing roles in mediating defenses responses against chewing and sucking insects. However, in some contexts such as in rice-BPH interactions, these phytohormones can have synergistic effects. Plants carrying the $B P H 6$ resistance gene exhibited more rapid increases in both SA and JA levels upon BPH infestation compared to susceptible plants. The application of exogenous SA and methyl jasmonate also enhanced resistance to BPH and reduced insect survival on both resistant and susceptible plant varieties (Guo et al. 2018).

Other hormones besides JA and SA also control insect defense responses in plants, including $\mathrm{CK}$, brassinosteroids (BR), gibberellins (GA), ethylene (ET), and abscisic acid (ABA). CK levels, and particularly the levels of the cis-zeatin (cZ) isoform levels, increased sharply in plants carrying the $\mathrm{BPH} 6$ resistance gene at $12-24 \mathrm{~h}$ post-BPH infestation with BPH compared with non-infested control plants. In addition, exogenous treatment with 6-benzylaminopurine, N6- $(\Delta 2-$ isopentenyl) adenine, and $\mathrm{cZ}$ reduced $\mathrm{BPH}$ survival and improved resistance in BPH6-expressing plants (Guo et al. 2018). BRs negatively regulate BPH resistance by decreasing SA levels and SA-associated gene expression while increasing JA levels and promoting JAassociated gene expression (Pan et al. 2018). The rice DELLA protein OsSLR1, which negatively regulates the GA pathway, also negatively regulates plant resistance to BPH. Silencing of OSSLR1 probably leading to decrease JA, and ET-mediated defense (Zhang et al. 2017). The OsGID1-mediated GA pathway positively regulates $\mathrm{BPH}$ resistance in rice. Overexpression of the GA receptor gene $O s G I D 1$ decrease $\mathrm{SA}$ and $\mathrm{H}_{2} \mathrm{O}_{2}$ level and the expression of SA-pathway-related WRKY transcripts, resulting in decreased BPH settling, laying, and feeding (Chen et al. 2018). ET is a stress hormone with a myriad of context-dependent effects on insect resistance. The silencing of OsACS2 reduced elicited ET emissions, TrypPI activity, and SSB resistance while improving resistance to $\mathrm{BPH}$ ( $\mathrm{Lu}$ et al. 2014). The exogenous application of ABA suppressed $\beta-1,3$ glucanase while inducing callose synthase activity, promoting callose deposition and thereby preventing BPH feeding (Liu et al. 2017). A recent study revealed that OsEIL1-OSLOX9 undergo crosstalk to negatively regulate JA and ET signaling pathways, thereby affecting plant responses to sucking insect attack (Ma et al. 2019).

Transcription factors that function downstream of hormonal signaling pathways are essential regulators of defense-associated signaling, making them vital to any insect resistance mechanisms in plants (Yang et al. 2016). Microarray and RNA-seq analyses showed that following BPH infestation, transcription factor genes are markedly upregulated in BPH-susceptible rice (Wang et al. 2012; Lv et al. 2014). The overexpression of OsWRKY89 led to increased leaf surface wax deposition, SA levels, and lignification in culms, resulting in enhanced WBPH resistance (Wang et al. 2007). OsWRKY70 activates TrypPI and enhances resistance against SSB by positively regulating JA biosynthesis while negatively regulating GA biosynthesis, thereby reducing plant resistance to $\mathrm{BPH}$ (Li et al. 2015b). The silencing of OsWRKY45 improved BPH resistance by increasing the induction of $\mathrm{H}_{2} \mathrm{O}_{2}$ and ET production by $\mathrm{BPH}$, thereby decreasing insect feeding, survival, nymphal development, and oviposition preferences (Huangfu et al. 2016). OsWRKY53 negatively regulates OsMPK3/6 to activate SSB resistance in rice, while also protecting against $\mathrm{BPH}$ via activating a burst of $\mathrm{H}_{2} \mathrm{O}_{2}$ production and suppressing ET biosynthesis (Hu et al. 
2015c, 2016b). In addition, OsHLH61 and OsbHLH96 affect plant responses to BPH by regulating pathogenrelated gene expression (Wang et al. 2019).

\section{Defense-related metabolites}

Plants synthesize a rich variety of metabolites, including defense compounds (e.g., proteinase inhibitors and callose), secondary metabolites (terpenes, alkaloids, flavonoid, and others), and volatiles. Many of these compounds, whose production is controlled by the signaling network, prevent insect pests from feeding, are toxic to insects, or attract their natural enemies (Douglas 2018; Yang et al. 2019).

Proteinase inhibitors (PIs) and callose are two common insect resistance compounds in rice. The PIs, whose production is triggered by insect feeding, affect digestive proteases and induce amino acid deficiencies in the insect midgut, thereby negatively affecting insect growth and development (Lison et al. 2006). TrypPIs are essential defense proteins that accumulate in rice in response to both BPH and SSB feeding (Du et al. 2009; Zhou et al. 2011). Callose deposition in BPH-resistant rice can blocks access to the phloem, thereby preventing insect feeding. By contrast, in susceptible rice varieties, $\mathrm{BPH}$ feeding induces the activation of callosehydrolyzing enzymes, leading to callose decomposition and thus benefiting the feeding process (Hao et al. 2008).

Secondary metabolites are also vital for defending plants against insect infestations, by reducing insect growth, attraction, survival, and reproduction. Infestation with BPH induces substantial metabolic changes in both resistant and susceptible rice varieties. BPH feeding increases sterol biosynthesis in susceptible plants, whereas it promotes wax biosynthesis, phytol metabolism, strengthening of GABA shunt, and shikimatemediated secondary metabolism in resistant plants (Liu et al. 2010; Zhang et al. 2018). Natural ovicidal resistance mechanisms also protect rice against planthoppers. Aqueous benzyl benzoate solutions are ovicidal to WBPH eggs at a concentration greater than $6.4 \mathrm{ppm}$ at $25^{\circ} \mathrm{C}$ (Seino et al. 1996). Similarly, oxalic acid, transaconite acid, and 3-nitraphthalic acid inhibit BPH sucking (Zhang et al. 1999; Ling et al. 2007). Feeding of the chewing insects $P$. guttata and $S$. mauritia induces the accumulation of phenolamides, which may be toxic to BPH (Alamgir et al. 2016). Phytoalexins are antimicrobial metabolites that are produced by plants upon pathogen and insect attack (Yamane 2013). BPH feeding and exogenous CK application led to much more robust increases in diterpenoid phytoalexins levels in plants expressing BPH6 relative to susceptible control plants (Guo et al. 2018). Serotonin, a ubiquitous compound across life forms, is also thought to regulate insect behavior and immune responses. Insect infestations result in increased serotonin biosynthesis in rice, and suppressing this process leads to increased SA levels and associated SSB and BPH resistance ( $\mathrm{Lu}$ et al. 2018). Finally, the flavonoid schaftoside was shown to inhibits the activation of the BPH kinase N1CDK1 by binding with this protein, resulting in suppressed ovary development and reduced the BPH fecundity and survival (Hao et al. 2018a, b).

The release of volatile compounds markedly increases upon insect infestation, thereby signaling the insect's locations to attract natural parasitoids and predator species (Allmann and Baldwin 2010). The production of $S$-linalool (monoterpene), an abundant volatile in rice, is strongly induced in response to $\mathrm{BPH}$. By contrast, $(E)$ - $\beta$-caryophyllene (sesquiterpene) is constitutively produced in rice, and its production is further induced in response to chewing insects but not BPH. Both two compounds attract BPH parasitoids and chewing herbivores (Cheng et al. 2007; Xiao et al. 2012). Green leaf volatiles are important mediators of plant defense response against planthopper. The loss of OsHPL3 expression results in increased levels of JA and decreased levels of green leaf volatiles, thereby altering planthopper performance and plant attraction (Tong et al. 2012; Wang et al. 2015a).

These findings suggest that a complex network regulates insect infestation in rice (Fig. 2). When insects feed on rice, PRRs in rice, such as OsLecRK perceive HAMPs or DAMPs, resulting in activation of the MAPK cascade and inducing pattern-triggered immunity (PTI). However, effectors secreted by insect saliva can prevent PTI. Resistance proteins, such as NLR proteins recognize these effectors to trigger ETI. In response to sucking insect attack, the $\mathrm{R}$ proteins combined with the transcription factors, activate the SA signaling pathway, resulting in increased SAresponsive defense gene expression and phytoalexin levels, as well as callose deposition. However, in response to chewing insect attack, the MAPK cascade activates JA signaling pathways, thus producing TryPIs and $\mathrm{H}_{2} \mathrm{O}_{2}$, enhancing the expression of JA-responsive defense genes to inhibit insect growth and development. 
Volatiles play indirect roles in plant defense by repelling insects settling and attracting natural enemies of insects.

The role of microRNA in regulating insect resistance in rice

MicroRNAs (miRNAs) are endogenous, $~ 21-24$ nucleotides long, non-coding small RNAs that are widely present in both animals and plants. These molecules specifically regulate the expression of their target genes by binding to complementary sequences to degrade mRNA or inhibit translation (Bartel 2009; Axtell and Meyers 2018). There are few reports on the roles of miRNA in regulating insect resistance in rice. BPHresponsive miRNAs in resistant and susceptible rice plants have been identified and analyzed (Wu et al. 2017). Recently, two miRNAs were shown to be involved in regulating of $\mathrm{BPH}$ resistance in rice. OsmiR156, a primary regulator of plant development, negatively regulates BPH resistance in rice by regulating the JA and JA-Ile biosynthetic pathway (Ge et al. 2018). The silencing of $m i R 156$ decreased the resistance of rice to BPH and reduced the honeydew excretion, as well as BPH survival and fecundity. Another miRNA in rice, OsmiR396, targets OsGRF8, encoding a growthregulating factor, and directly regulates $O S F 3 H$, encoding a flavanone 3-hydroxylase in the flavonoid biosynthetic pathway, thereby negatively regulating BPH resistance (Dai et al. 2019). miRNAs are involved in many developmental processes in plants and play important roles in abiotic and biotic stress responses (Bartel 2009; Wu et al. 2017). This mechanism provides an ideal way to balance insect resistance, defense responses, and crop growth.

\section{Breeding for insect-resistant rice}

The ultimate aim of mapping and cloning insect resistance genes, and elucidating the molecular mechanism of insect-resistant in crops is to breed insect-resistant crop varieties, representing an effective, economical, and environmentally friendly pest control strategy. Currently available genetic technologies, including markerassisted selection (MAS), genetic transformation, and genome editing can be used to reduce the timescales of insect-resistant plant breeding are essential for use with crops with limited insect resistance resources.
Marker-assisted selection

To date, MAS has been successfully utilized to breed plants with major BPH, GM, WBPH, and GRH resistance genes. A series of near-isogenic lines (NILs) with a single $\mathrm{BPH}$ resistance gene/QTL, including ВPH3, bph4, ВРH6, ВPH9, ВPH10, BPH14, BPH15, ВPH17, ВPH18, ВPH20, ВPH21, ВPH24, $B P H 26, B P H 32, q B P H 3$, and $q B P H 4$, were developed in the background of the susceptible cultivar 9311 and IR24, respectively (Qiu et al. 2010; Xiao et al. 2016; Jena et al. 2017). Furthermore, the NILs with a single GM (GM4, GM11), WBPH (Ovc, qOVA-1-3, qOVA-4, qOVA-5-1, and qOVA-5-2), and GRH (GRH1, GRH2, GRH4, GRH5, GRH6, and qGRH4) resistance genes were also developed (Yamasaki et al. 2003; Fujita et al. 2010b; Himabindu et al. 2010; Divya et al. 2015). Unfortunately, such plants bearing single resistance genes lost their efficacy in just a few years as the insect populations rapidly adapted or evolved to overcome the resistance (Jena and Kim 2010). The use of different resistance genes in breeding or pyramiding multiple insect resistance genes into a given rice variety represents an ideal means for achieving the sustained control of insects in rice. Rice varieties harboring multiple pyramided BPH resistance genes exhibited more robust resistance towards BPH than plants bearing single resistance genes (Sharma et al. 2004; Qiu et al. 2011; Liu et al. 2016b). The pyramided lines (PYLs) with two- to three-pyramided BPH resistance genes have been developed. The pyramided genes had an additive effect, with an order of effectiveness of three-pyramided genes $>$ two-pyramided genes $>$ single gene $>$ none (Hu et al. 2013; Jena et al. 2017). Similarly, three PYLs possessing GRH2 and GRH6, GRH4, and GRH6, or GRH5 and $q G R H 4$, showed higher resistance levels than each of the five monolocus NILs with the same loci (Fujita et al. 2010b). In addition, Wang et al. (2017) pyramided BPH6 and BPH9 into rice variety 9311 , founding that hybrids heterozygous for $\mathrm{BPH} 6$ and $\mathrm{BPH} 9$ were highly resistant to BPH. A marker-assisted selection has become popular for molecular breeding in crop improvement and should contribute to future breeding outcomes. In China, various male-sterile lines, restoring lines, and hybrid varieties carrying the BPH14 and BPH15 genes by MAS have been developed and released to the farmers (Hu et al. 2013; Wang et al. 2016; He et al. 2019). 
Bt and lectins toxins

Bt proteins are insecticidal toxins produced by $B$. thuringiensis. The use of Bt genes in insect pest management has attracted increasing attention. There are more than $200 \mathrm{Bt}$ genes, each of which is highly specific to a range of insects. The first transgenic $\mathrm{Bt}$ crops that were grown commercially were $\mathrm{Bt}$ corn and cotton (Douglas 2018). Bt genes are highly effective against chewing insects in rice, making them ideal targets for the control of SSB and RLF. For example, transgenic rice expressing the Bt gene cry $2 \mathrm{AX} 1$ exhibited increased resistance to multiple lepidopteran pests (Chakraborty et al. 2016). However, several pests have recently developed resistance to overcome Bt crops in the field (Tabashnik et al. 2013). This problem could be solved by pyramiding multiple Bt genes or enhancing the efficacy of Bt toxins. Indeed, transgenic plants expressing a fusion protein of Cyr1Ab and Vip3A were highly resistant to SSB and RLF, with no adverse effect on agronomic traits (Xu et al. 2018a). A recombinational product of $\mathrm{Cry} 2 \mathrm{Aa}$ and $\mathrm{Cry} 2 \mathrm{Ac}$ increased the efficacy of Bt toxin (Chakraborty et al. 2016).

Although the use of Bt toxins is a common method for the biological control of pests, these compounds are ineffective against Hemipteran pests. Pyramiding multiple genes, such as $\mathrm{BPH14}, \mathrm{BPH15}$, and CrylC in elite restorer lines enhanced resistance to $\mathrm{BPH}, \mathrm{SSB}$, and RLF (Wan et al. 2014). A fusion protein consisting of the DI and DII domains of Bt CrylAc and the carbohydrate-binding domain of garlic lectin showed remarkable toxicity against Lepidopteran and Hemipteran insects (Boddupally et al. 2018). In addition, a field survey showed that $\mathrm{Bt}$ rice contained fewer settled $\mathrm{BPHs}$ than non-Bt rice, even though BPHs are insensitive to $\mathrm{Bt}$ Cry proteins, providing the first example of the ecological resistance of Bt plants against non-target pests (Wang et al. 2018b). These studies provide new ideas for the future development of genetically engineered crops with resistance to multiple insects.

Lectins are a potent form of insecticidal compounds that are well-suited to control sap-sucking insects in rice that are not susceptible to Bt toxins. Insect pests feeding on plants expressing snowdrop lectin (GNA) showed impaired growth, development, and reproduction (Rao et al. 1998; Sun et al. 2002; Nagadhara et al. 2004). However, the resistance mediated by GNA is not as effective as that mediated by $\mathrm{Bt}$ or by resistance genes in rice germplasm. Therefore, the appropriate stacking of genes can be used to optimize the efficacy and specificity of insect resistance. For example, a fusion protein comprising GNA and the scorpion neurotoxin domain conferred resistance and toxicity to Lepidopteran and Hemipteran pests in rice (Liu et al. 2016a).

\section{Plant-mediated RNA interference}

The planet-mediated RNA interference (RNAi) is a promising strategy for insect control involving the expression of double-stranded (ds) insect RNA in crops. This technique has a better mode of action and specificity than the use of protein toxins. When insect pests feed on a crop expressing dsRNA specific to an important insect gene, the dsRNA is internalized into cells and processed into small interfering RNA, which degrades the complementary target mRNAs or interferes with its translation (Scott et al. 2013). Plant-mediated RNAi has been widely employed against Lepidopteran and Coleopteran insects (Baum et al. 2007; Mao et al. 2007; Scott et al. 2013). Zha et al. (2011) first reported that insect feeding on transgenic rice expressing dsRNA from Hemipteran insects exhibited reduced transcript levels of the targeted genes in their midguts. The survival of BPH or Asian corn borers decreased significantly when fed on rice or maize soaked in a solution containing $d s C e s$ (carboxylesterase gene) or $d s K T I$ (Kunitz-type trypsin inhibitors gene) ( $\mathrm{Li}$ et al. 2015a). Shangguan et al. (2018) demonstrated that the expressing dsNlMLP in rice impaired salivary sheath formation and significantly reduced the rate of weight gain and survival of BPHs fed on these plants.

Although many attractive target Hemipteran genes have been selected, only a few successful examples of their use have been reported. Therefore, a major challenge for insect control by plant-mediated RNAi is to determine how to efficiently and economically transfer dsRNA into insects through transgenic expression in rice.

\section{Genome editing by CRISPR/Cas9}

Genome editing is a rapidly developing technology that has dramatically increased the chances of introducing resistance traits into crops by generating highly specific, precise targeted mutations into plant genomes. A major genome-editing tool is the CRISPR/Cas9 system (Georges and Ray 2017). The first report of the successful use of CRISPR/Cas9 to engineer insect resistance 
involved its use in conferring resistance to viruses carried by insects, particularly geminiviruses with DNA genomes (Ali et al. 2016). Knocking out CYP71A1 (encoding tryptamine 5-hydroxylase) by CRISPR/Cas9 increased SA levels and decreased serotonin levels in rice, thus enhancing resistance to $\mathrm{BPH}$ (Lu et al. 2018). CRISPR/Cas 9 could be used to breed new resistant crop varieties by converting a susceptible allele to a resistance allele via editing, thereby eliminating the need for the extensive backcrosses required in traditional breeding.

In summary, although MAS is still used to breed new crop varieties, the rapid development and ongoing innovations in plant genetic technologies providing more effective approaches to engineer insect-resistant crops over the coming years.

\section{Outlook}

Marked progress has been made in recent years to map, clone, elucidate the underlying resistance mechanisms, and leverage insect resistance genes in rice, allowing for a better understanding of the molecular basis of such resistance and facilitating efforts to breed insectresistant rice varieties. However, many challenges remain in our efforts to achieve reliable insect resistance in rice.

As rice resistance to insects in rice coevolved with the insects themselves, insect resistance genes are more frequent in regions of the world where pests are more common. Therefore, efforts to more thoroughly screen rice germplasm resources in these regions will provide the opportunity to identify additional insect resistance germplasms. The 3000 Rice Genome Project has resequenced a core collection of 3000 rice accessions from 89 countries to an average sequencing depth of 14× (The 3000 Rice Genomes Project 2014). This and other high-throughput sequencing efforts and related SNP data offer an opportunity to leverage genomewide association studies to detect and exploit insect resistance genes. The findings of such studies offer ways to better analyze allelic variations and distributions in insect resistance genes within the germplasm, enabling studies of their origins and evolution.

Over the past decade, rapid technological advances have been made in the discovery and analysis of plant and insect genomes, transcriptomes, proteomes, and secretomes. These techniques have provided the impetus to identify putative insect effectors, clone insect resistance genes, and reveal the signaling pathways and key components of plant-insect resistance signals. However, there is still a major gap in our understanding of insect-plant interactions. No effectors corresponding to the $R$ gene have yet been identified, although 14 insect resistance genes (encoding LecRK and NLR proteins) have been cloned in rice. Similarly, although three effectors have been identified from Hessian flies, the corresponding $R$ genes have not been cloned. The roles of hormone signaling and the corresponding regulatory genes involved in insect resistance in rice have been discovered, and a preliminary regulatory network has been constructed (Fig. 2). However, the roles of insect resistance genes in this network are still unclear. Furthermore, no substances that are lethal to insects have been identified in rice. Studies aimed at addressing these issues will provide a more thorough understanding of how these resistance proteins recognize and mediate effector-triggered signaling and immunity against insects.

Whereas most insect resistance genes characterized to date have arisen through long-term natural or artificial selection and do not appear to adversely affect rice yields, such resistance responses do require energy consumption. When overzealous, these responses can adversely affect crop yields. Recently, two miRNAs were shown to be involved in regulating of BPH resistance in rice (Ge et al. 2018; Dai et al. 2019). However, multifunctional miRNAs could cause an imbalance between insect resistance and crop growth and development. Once we have obtained a more comprehensive understanding of the regulatory mechanisms governing this delicate balance, such knowledge could be used in future research efforts offer to design better ways to cultivate novel varieties of high-quality insect-resistant rice.

Because multiple insect pests are simultaneously present in the field, the indiscriminate use of insecticides for pest management is more practical, economical, and effective than growing insect-specific resistant rice varieties. Therefore, insect resistance breeding must involve the incorporation of broad-spectrum resistance genes to minimize the investment in crop management, making this technique more suitable for meeting the expected return on investment of rice farmers in the future. Now, MAS has already been used to pyramid multiple insect resistance genes to cultivate durable, broad-spectrum insect resistance rice. However, new emerging technologies such as CRISPR/Cas9 gene 
editing to convert insect susceptible alleles to insect resistance alleles, as well as altering the levels of specific secondary metabolites in vivo, provide the potential to design crops that can be patched in real time to combat evolving pests. Furthermore, these emerging technologies will be invaluable for uncovering the roles of insect effectors and plant target proteins in the regulation of plant immunity.

Funding information This study was supported by grants from the National Program on Research \& Development of Transgenic Plants (2018ZX0800101B), the National Natural Science Foundation of China (31630063), and the National Key Research and Development Program (2016YFD0100600).

Open Access This article is licensed under a Creative Commons Attribution 4.0 International License, which permits use, sharing, adaptation, distribution and reproduction in any medium or format, as long as you give appropriate credit to the original author(s) and the source, provide a link to the Creative Commons licence, and indicate if changes were made. The images or other third party material in this article are included in the article's Creative Commons licence, unless indicated otherwise in a credit line to the material. If material is not included in the article's Creative Commons licence and your intended use is not permitted by statutory regulation or exceeds the permitted use, you will need to obtain permission directly from the copyright holder. To view a copy of this licence, visit http://creativecommons.org/licenses/by/4.0/.

\section{References}

Aggarwal R, Subramanyam S, Zhao C, Chen MS, Harris MO, Stuart JJ (2014) Avirulence effector discovery in a plant galling and plant parasitic arthropod, the Hessian fly (Mayetiola destructor). PLoS One 9:e100958

Alamgir KM, Hojo Y, Christeller JT, Fukumoto K, Isshiki R, Shinya T, Baldwin IT, Galis I (2016) Systematic analysis of rice (Oryza sativa) metabolic response to herbivory. Plant Cell Environ 39:453-466

Alborn HT, Hansen TV, Jones TH, Bennett DC, Tumlinson JH, Schmelz EA, Teal PE (2007) Disulfooxy fatty acids from the American bird grasshopper Schistocerca americana, elicitors of plant volatiles. Proc Natl Acad Sci U S A 104:1297612981

Ali Z, Ali S, Tashkandi M, Zaidi SS, Mahfouz MM (2016) CRISPR/Cas9-mediated immunity to geminiviruses: differential interference and evasion. Sci Rep 6:26912

Allmann S, Baldwin IT (2010) Insects betray themselves in nature to predators by rapid isomerization of green leaf volatiles. Science 329:1075-1078

Angeles ER, Khush GS (1999) A new gene for resistance to green leafhopper, Nephotettix virescens (distant) in rice. Rice Genet News 16:93-94

Angeles ER, Khush GS (2000a) Genetic analysis of resistance to green leafhopper, Nephotettix virescens (distant), in three varieties. Plant Breed 119:446-448
Angeles ER, Khush GS (2000b) Genetics of resistance to green leafhopper in five cultivars of rice, Oryza sativa L. SABRAO J Breed Genet 32:1-4

Angeles ER, Khush GS, Heinrichs EA (1981) New genes for resistance to whitebacked planthopper in rice. Crop Sci 21: 47-50

Athwal DS, Pathak MD, Bacalangco E, Pura CD (1971) Genetics of resistance to brown planthoppers and green leaf hoppers in Oryza sativa L. Crop Sci 11:747-750

Axtell MJ, Meyers BC (2018) Revisiting criteria for plant microRNA annotation in the era of big data. Plant Cell 30: 272-284

Backus EA, Serrano MS, Ranger CM (2005) Mechanisms of hopperburn: an overview of insect taxonomy, behavior, and physiology. Annu Rev Entomol 50:125-151

Bartel DP (2009) MicroRNAs: target recognition and regulatory functions. Cell 136:215-233

Baum JA, Bogaert T, Clinton W, Heck GR, Feldmann P, IlAGAN O, Johnson S, Plaetinck G, Munyikwa PM (2007) Control of coleopteran insect pests through RNA interference. Nat Biotechnol 25:1322-1326

Biradar SK, Sundaram RM, Thirumurugan T, Bentur JS, Amudhan S, Shenoy VV, Mishra B, Bennett J, Sarma NP (2004) Identification of flanking SSR markers for a major rice gall midge resistance gene Gmland their validation. Theor Appl Genet 109:1468-1473

Boddupally D, Tamirisa S, Gundra SR, Vudem DR, Khareedu VR (2018) Expression of hybrid fusion protein (Cry1Ac::ASAL) in transgenic rice plants imparts resistance against multiple insect pests. Sci Rep 8:8458

Brar DS, Khush GS (2006) Cytogenetic manipulation and germplasm enhancement of rice (Oryza sativa L.). In: Singh RJ, Jauhar PP (eds) Genetic resources, chromosome engineering and crop improvement. CRC, Boca Raton, pp 115-158

Cha YS, Ji H, Yun DW, Ahn BO, Lee MC, Suh SC, Lee CS, Ahn EK, Jeon YH, Jin ID, Sohn JK, Koh HJ, Eun MY (2008) Fine mapping of the rice Bph1 gene, which confers resistance to the brown planthopper (Nilaparvata lugens Stål), and development of STS markers for marker-assisted selection. Mol Cells 26:146-151

Chakraborty M, Reddy PS, Mustafa G, Rajesh G, Narasu VM, Udayasuriyan V, Rana D (2016) Transgenic rice expressing the $C r y 2 A X 1$ gene confers resistance to multiple lepidopteran pests. Transgenic Res 25:665-678

Chen MS (2008) Inducible direct plant defense against insect herbivores: a review. Insect Sci 15:101-144

Chen J, Wang L, Pang X, Pan Q (2006) Genetic analysis and fine mapping of a rice brown planthopper (Nilaparvata lugens Stål) resistance gene $\operatorname{bph19}(t)$. Mol Genet Genomics 275: 321-329

Chen J, Huang DR, Wang L, Liu GJ (2010) Identification of quantitative trait loci for resistance to whitebacked planthopper, Sogatella furcifera, from an interspecific cross Oryza sativa $\times$ O. rufpogon. Breed Sci 60:153-159

Chen YH, Gols R, Benrey B (2015) Crop domestication and its impact on naturally selected trophic interactions. Annu Rev Entomol 60:35-58

Chen L, Cao T, Zhang J, Lou Y (2018) Overexpression of OsGID1 enhances the resistance of rice to the brown planthopper Nilaparvata lugens. Int J Mol Sci 19:E2744 
Cheng AX, Xiang CY, Li JX, Yang CQ, Hu WL, Wang LJ, Lou YG, Chen XY (2007) The rice (E)-beta-caryophyllene synthase (OsTPS3) accounts for the major inducible volatile sesquiterpenes. Phytochemistry 68:1632-1641

Cheng X, Wu Y, Guo J, Du B, Chen R, Zhu L, He G (2013a) A rice lectin receptor-like that is involved in innate immune responses also contributes to seed germination. Plant J 76: 687-698

Cheng X, Zhu L, He G (2013b) Towards understanding of molecular interactions between rice and the brown planthopper. Mol Plant 6:621-634

Crist E, Mora C, Engelman R (2017) The interaction of human population, food production, and biodiversity protection. Science 356:260-264

Dai Z, Tan J, Zhou C, Yang X, Yang F, Zhang S, Sun S, Miao X, Shi Z (2019) The OsmiR396-OsGRF8-OsF3H-flavonoid pathway mediates resistance to the brown planthopper in rice (Oryza sativa). Plant Biotechnol J 17:1657-1669

Deen R, Ramesh K, Gautam SK, Rao YK, Lakshmi VJ, Viraktamath BC, Brar DS, Ram T (2010) Identification of new gene for BPH resistance introgressed from $O$. rufpogon. Rice Genet News1 25:70-71

Deutsch CA, Tewksbury JJ, Tigchelaar M, Battisti DS, Merrill SC, Huey RB, Naylor RL (2018) Increase in crop losses to insect pests in a warming climate. Science 361:916-919

Divya D, Himabindu K, Nair S, Bentur JS (2015) Cloning of a gene encoding LRR protein and its validation as candidate gall midge resistance gene Gm4, in rice. Euphytica 203:185195

Divya D, Sahu N, Nair S, Bentur JS (2018) Map-based cloning and validation of a gall midge resistance gene, $\operatorname{Gm} 8$, encoding a proline-rich protein in the rice variety Aganni. Mol Biol Rep 45:2075-2086

Douglas AE (2018) Strategies for enhanced crop resistance to insect pests. Annu Rev Plant Biol 69:637-660

Du B, Zhang WL, Liu B, Hu J, Wei Z, Shi ZY, He RF, Zhu LL, Chen RZ, Han B, He GC (2009) Identification and characterization of Bph14, a gene conferring resistance to brown planthopper in rice. Proc Natl Acad Sci U S A 106:2216322168

Duan CX, Cheng ZJ, Lei CL, Zhai HQ, Wan J (2009) Analysis of QTLs for resistance to small brown planthopper (Laodelphax striatellus fallén) in rice (Oryza sativa $\mathrm{L}$.) using an $\mathrm{F}_{2}$ population from a cross between Mudgo and Wuyujing 3. Acta Agron Sin 35:388-394

Duan CX, Su N, Cheng ZJ, Lei CL, Wang JL, Zhai HQ, Wan J (2010) QTL analysis for the resistance to small brown planthopper (Laodelphax striatellus fallen) in rice using backcross inbred lines. Plant Breed 129:63-67

Duan C, Yu J, Bai J, Zhu Z, Wang X (2014) Induced defense responses in rice plants against small brown planthopper infestation. Crop J 2:55-62

Dubey M, Chandel G (2010) In silico survey and characterization of resistance gene analogues (RGAs) in the genomic regions encompassing gall midge resistance genes $G m 4$ and $G m 5$ in rice (Oryza sativa L.). Plant Omics J 3:140-148

Fan D, Liu Y, Zhang H, He J, Huang F, Huang S, Wu B, Liu D, Wen P, Liu L, Jiang L, Cheng X, Wan J (2018) Identification and fine mapping of $q W B P H 11$ conferring resistance to whitebacked planthopper (Sogatella furcifera Horvath) in rice (Oryza sativa L.). Mol Breed 38:96
Fujita D, Doi K, Yoshimura A, Yasui H (2004) Introgression of a resistance gene for green rice leafhopper from Oryza nivara into cultivated rice, Oryza sativa L. Rice Genet Newslett 21: 64-66

Fujita D, Doi K, Yoshimura A, Yasui H (2006) Molecular mapping of a novel gene, Grh5, conferring resistance to green rice leafhopper (Nephotettix cincticeps Uhler) in rice Oryza sativa L. Theor Appl Genet 113:567-573

Fujita D, Doi K, Yoshimura A, Yasui H (2010a) A major QTL for resistance to green rice leafhopper (Nephotettix cincticeps Uhler) derived from African rice (Oryza glaberrima Steud.). Breed Sci 60:336-341

Fujita D, Yoshimura A, Yasui H (2010b) Development of near isogenic lines and pyramided lines carrying resistance genes to green rice leafhopper (Nephotettix cincticeps Uhler) with the Taichung 65 genetic background in rice (Oryza sativa L.). Breed Sci 60:18-27

Fujita D, Kohli A, Horgan FG (2013) Rice resistance to planthoppers and leafhoppers. Crit Rev Plant Sci 32:162-191

Fukumoto K, Alamgir K, Yamashita Y, Mori IC, Matsuura H, Galis I (2013) Response of rice to insect elicitors and the role of OsJAR1 in wound and herbivory-induced JA-Ile accumulation. J Integr Plant Biol 55:775-784

Ge Y, Han J, Zhou G, Xu Y, Ding Y, Shi M, Guo C, Wu G (2018) Silencing of miR156 confers enhanced resistance to brown planthopper in rice. Planta 248:813-826

Georges F, Ray H (2017) Genome editing of crops: a renewed opportunity for food security. GM Crops Food 8:1-12

Ghani MU, Khush GS (1998) A new gene for resistance to green leafhopper Nephotettix virescens (distant) in rice. J Genet 67: 151-159

Ghauri MSK (1971) Revision of the genus Nephotettix Matsumura (Homoptera: Cicadelloidea: Euscelidae) based on the type material. Bull Entomol Res 60:481-512

Grist DH, Lever RJ (1969) Pests of rice[M]. Longmans, Green and Co, London, p 520

Guo J, Xu C, Wu D, Zhao Y, Qiu Y, Wang X, Ouyang Y, Cai B, Liu X, Jing S, Shangguan X, Wang H, Ma Y, Hu L, Wu Y, Shi S, Wang W, Zhu L, Xu X, Chen R, Feng Y, Du B, He G (2018) Bph6 encodes an exocyst-localized protein and confers broad resistance to planthoppers in rice. Nat Genet 50 : 297-306

Hao PY, Liu CX, Wang YY, Chen RZ, Tang M, Du B, Zhu LL, He GC (2008) Herbivore-induced callose deposition on the sieve plates of rice: an important mechanism for host resistance. Plant Physiol 146:1810-1820

Hao P, Ma Y, Feng Y, Lu C, Yu X (2018a) NlCDK1 gene is required for the ovarian development and survival of the brown planthopper, Nilaparvata lugens Stål, as revealed by RNA interference. J Asia Pac Entomol 21:316-321

Hao P, Feng Y, Zhou Y, Song X, Li H, Ma Y, Ye C, Yu X (2018b) Schaftoside interacts with NICDK1 protein: a mechanism of rice resistance to brown planthopper, Nilaparvata lugens. Front Plant Sci 9:710

Hattori M, Komatsu S, Noda H, Matsumoto Y (2015) Proteome analysis of watery saliva secreted by green rice leafhopper, Nephotettix cincticeps. PLoS One 10:e0123671

He G, Du B, Chen R (2013a) Insect resistance. In: Zhang Q, Wing RA (eds) Genetics and genomics of rice. Springer, Berlin, pp 177-192 
He J, Liu YQ, Liu YL, Jiang L, Wu H, Kang H, Liu S, Chen L, Liu X, Cheng X, Wan J (2013b) High-resolution mapping of brown planthopper $(\mathrm{BPH})$ resistance gene $B p h 27(t)$ in rice (Oryza sativa L.). Mol Breed 31:549-557

He C, Xiao Y, Yu J, Li J, Meng Q, Qing X, Xiao G (2019) Pyramiding Xa21, Bph14, and Bph15 genes into the elite restorer line Yuehui9113 increases resistance to bacterial blight and the brown planthopper in rice. Crop Prot 115: 31-39

Hernandez JE, Khush GS (1981) Genetics of resistance to whitebacked planthopper in some rice (Oryza sativa L.) varieties. Oryza 18:44-50

Hettenhausen C, Schuman MC, Wu J (2015) MAPK signaling: a key element in plant defense response to insects. Insect Sci 22:157-164

Himabindu K, Sundaram RM, Neeraia CN, Mishra B, Bentur JS (2007) Flanking SSR markers for allelism test for the Asian rice gall midge (Orseolia oryzae) resistance genes. Euphytica 157:267-279

Himabindu K, Suneetha K, Sama VSAK, Bentur JS (2010) A new rice gall midge resistance gene in the breeding line CR57MR1523, mapping with flanking markers and development of NILs. Euphytica 174:179-187

Hirabayashi H, Angeles ER, Kaji R, Ogawa T, Brar DS, Khush GS (1998) Identifcation of the brown planthopper resistance gene derived from $O$. officinalis using molecular markers in rice. Breed Sci 48:82

Hirabayashi H, Ideta O, Sato H, Takeuchi Y, Ando I, Nemoto H, Imbe T, Brar DS, Ogawa T (2004) Identification of a resistance gene to brown planthopper derived from Oryza minuta in rice. Breed Res 6:285

Hou LY, Yu P, Xu Q, Yuan XP, Yu HY, Wang YP, Wang CH, Wan G, Tang SX, Peng ST, Wei XH (2011) Genetic analysis and preliminary mapping of two recessive resistance genes to brown planthopper, Nilaparvata lugens Stål in rice. Rice Sci 18:238-242

Hu J, Zhou J, Peng X, Xu H, Liu C, Du B, Yuan H, Zhu L, He G (2011) The Bphi008a gene interacts with the ethylene pathway and transcriptionally regulates MAPK genes in the response of rice to brown planthopper feeding. Plant Physiol 156:856-872

Hu J, Cheng M, Gao G, Zhang Q, Xiao J, He Y (2013) Pyramiding and evaluation of three dominant brown planthopper resistance genes in the elite indica rice 9311 and its hybrids. Pest Manag Sci 69:802-808

Hu J, Xiao C, Cheng M, Gao G, Zhang Q, He Y (2015a) A new finely mapped Oryza australiensis-derived QTL in rice confers resistance to brown planthopper. Gene 561:132-137

Hu J, Xiao C, Cheng M, Gao G, Zhang Q, He Y (2015b) Fine mapping and pyramiding of brown planthopper resistance genes $Q B p h 3$ and $Q B p h 4$ in an introgression line from wild rice $O$. officinalis. Mol Breed 35:3

Hu L, Ye M, Li R, Zhang T, Zhou G, Wang Q, Lu J, Lou Y (2015c) The rice transcription factor WRKY53 suppresses herbivoreinduced defenses by acting as a negative feedback modulator of mitogen-activated protein kinase activity. Plant Physiol 169:2907-2921

Hu J, Xiao C, He Y (2016a) Recent progress on the genetics and molecular breeding of brown planthopper resistance in rice. Rice 9:30
Hu L, Ye M, Li R, Lou Y (2016b) OsWRKY53, a versatile switch in regulating herbivore-induced defense responses in rice. Plant Signal Behav 11:e1169357

Hu L, Wu Y, Wu D, Rao W, Guo J, Ma Y, Wang Z, Shangguan X, Wang H, Xu C, Huang J, Shi S, Chen R, Du B, Zhu L, He G (2017) The coiled-coil and nucleotide binding domains of brown planthopper resistance14 function in signaling and resistance against planthopper in rice. Plant Cell 29:31573185

Hu J, Chang X, Zou L, Tang W, Wu W (2018) Identification and fine mapping of $B p h 33$, a new brown planthopper resistance gene in rice (Oryza sativa L.). Rice 11:55

Hua H, Lu Q, Xu C, Zhou D, Li X, Zhang Q (2007) Analysis of rice genes induced by striped stemborer (Chilo suppressalis) attack identified a promoter fragment highly specifically responsive to insect feeding. Plant Mol Biol 65:519-530

Huang YL, Shu LH, Zhu LL, Liao LJ, He GC (2000) Characterization of the intersectional hybrid between Oryza sativa and $O$. meyeriana indigenous to China. J Wuhan Univ 46:739-744

Huang Z, He GC, Shu LH, Li XH, Zhang Q (2001) Identification and mapping of two brown planthopper resistance genes in rice. Theor Appl Gene 102:923-934

Huang D, Qiu Y, Zhang Y, Huang F, Meng J, Wei S, Li R, Chen B (2013) Fine mapping and characterization of $B P H 27$, a brown planthopper resistance gene from wild rice (Oryza rufpogon Griff.). Theor Appl Genet 126:219-229

Huang HJ, Lu JB, Li Q, Bao YY, Zhang CX (2018) Combined transcriptomic/proteomic analysis of salivary gland and secreted saliva in three planthopper species. J Proteome 172: 25-35

Huang HJ, Cui JR, Xia X, Chen J, Ye YX, Zhang CX, Hong XY (2019) Salivary DNase II from Laodelphax striatellus acts as an effector that suppresses plant defence. New Phytol 224: 860-874

Huangfu J, Li J, Li R, Ye M, Kuai P, Zhang T, Lou Y (2016) The transcription factor OsWRKY45 negatively modulates the resistance of rice to the brown planthopper Nilaparvata lugens. Int J Mol Sci 17:e697

Ishii T, Brar DS, Multani DS, Khush GS (1994) Molecular tagging of genes for brown planthopper resistance and earliness introgressed from Oryza australiensis into cultivated rice, $O$ sativa. Genome 37:217-221

Jairin J, Teangdeerith SN, Leelagud P, Phengrat K, Vanavichi A, Toojindra T (2007a) Detection of brown planthopper resistance genes from different rice mapping populations in the same genomic location. Sci Asia 33:347-352

Jairin J, Teangdeerith SN, Leelagud P, Phengrat K, Vanavichit A, Toojinda T (2007b) Physical mapping of Bph3, a brown planthopper resistance locus in rice. Maejo Int J Sci Tech 1: $166-177$

Jairin J, Sansen K, Wonboon W, Kothcharerk J (2010) Detection of a brown planthopper resistance gene bph4 at the same chromosomal position of Bph3 using two different genetic backgrounds of rice. Breed Sci 60:71-75

Jena KK, Kim SM (2010) Current status of brown planthopper $(\mathrm{BPH})$ resistance and genetics. Rice 3:161-171

Jena KK, Hechanova SL, Verdeprado H, Prahalada GD, Kim SR (2017) Development of 25 near-isogenic lines (NILs) with ten $\mathrm{BPH}$ resistance genes in rice (Oryza sativa L.): 
production, resistance spectrum, and molecular analysis. Theor Appl Genet 130:2345-2360

Ji H, Kim SR, Kim YH, Suh JP, Park HM, Sreenivasulu N, Misra G, Kim SM, Hechanova SL, Kim H, Lee GS, Yoon UH, Kim TH, Lim H, Suh SC, Yang J, An G, Jena KK (2016) Mapbased cloning and characterization of the $\mathrm{BPH} 18$ gene from wild rice conferring resistance to brown planthopper (BPH) insect pest. Sci Rep 6:34376

Ji R, Ye W, Chen H, Zeng J, Li H, Yu H, Li J, Lou Y (2017) A salivary endo- $\beta-1,4$-glucanase acts as an effector that enables the brown planthopper to feed on rice. Plant Physiol 173:1920-1932

Jing S, Liu B, Peng L, Peng X, Zhu L, Fu Q, He G (2012) Development and use of EST-SSR markers for assessing genetic diversity in the brown planthopper (Nilaparvata lugens Stål). Bull Entomol Res 102:113-122

Jing S, Zhang L, Ma Y, Liu B, Zhao Y, Yu H, Zhou X, Qin R, Zhu L, He G (2014) Genome-wide mapping of virulence in brown planthopper identifies loci that break down host plant resistance. PLoS One 9:e98911

Jing S, Zhao Y, Du B, Chen R, Zhu L, He G (2017) Genomics of interaction between the brown planthopper and rice. Curr Opin Insect Sci 19:82-87

Kabir MA, Khush GS (1988) Genetic analysis of resistance to brown planthopper resistance gene in rice (Oryza sativa L.). Plant Breed 100:54-58

Kadowaki M, Yoshimura A, Yasui H (2003) RFLP mapping of antibiosis to rice green leafhopper. In: Khush GS, Brar DS, Hardy B (eds) Advances in rice genetics. International Rice Research Institute, Los Baños, pp 270-272

Kaloshian I, Walling LL (2016) Hemipteran and dipteran pests: effectors and plant host immune regulators. J Integr Plant Biol 58:350-361

Katiyar SK, Tan Y, Huang B, Chandel G, Xu Y, Zhang Y, Xie Z, Bennett J (2001) Molecular mapping of gene Gm6-(t) which confers resistance against four biotypes of Asian rice gall midge in China. Theor Appl Genet 103:953-961

Khush GS, Virk PS (2005) IR Varieties and Their Impact. International Rice Research Institute, Los Banos, Philippines

Khush GS, Karim ANMR, Angeles ER (1985) Genetics of resistance of rice cultivar ARC10550 to Bangladesh brown planthopper biotype. J Genet 64:121-125

Kobayashi T, Yamamoto K, Suetsugu Y, Kuwazaki S, Hattori M, Jairin J, Sanada-Morimura S, Matsumura M (2014) Genetic mapping of the rice resistance-breaking gene of the brown planthopper Nilaparvata lugens. Proc Biol Sci 281:1787

Kumar A, Jain A, Sahu RK, Shrivastava MN, Nair S, Mohan M (2005) Genetic analysis of resistance genes for the rice gall midge in two rice genotypes. Crop Sci 45:1631-1635

Kumar K, Sarao PS, Bhatia D, Neelam K, Kaur A, Mangat GS, Brar DS, Singh K (2018) High-resolution genetic mapping of a novel brown planthopper resistance locus, Bph34 in Oryza sativa L. $\times$ Oryza nivara (Sharma \& Shastry) derived interspecific $F_{2}$ population. Theor Appl Gene 131:1163-1171

Laksminarayana A, Khush GS (1977) New genes for resistance to the brown planthopper in rice. Crop Sci 17:96-100

Li X, Zhai H, Wan J, Ma L, Zhuang J, Liu G, Yang C (2004) Mapping of a new gene $\operatorname{Wbph} 6(t)$ resistant to the whitebacked planthopper, Sogatella furcifera, in rice. Rice Sci 11:86-90
Li R, Li L, Wei S, Wei Y, Chen Y, Bai D, Yang L, Huang F, Lu W, Zhang X, Li X, Yang X, Wei Y (2006) The evaluation and utilization of new genes for brown planthopper resistance in common wild rice (Oryza rufpogon Griff.). Mol Plant Breed 4:365-371

Li J, Shang K, Liu J, Jiang T, Hu D, Hua H (2014) Multigenerational effects of rice harboring Bph15 on brown planthopper, Nilaparvata lugens. Pest Manag Sci 70:310337

Li H, Guan R, Guo H, Miao X (2015a) New insights into an RNAi approach for plant defence against piercing-sucking and stem-borer insect pests. Plant Cell Environ 38:2277-2285

Li R, Zhang J, Li J, Zhou G, Wang Q, Bian W, Erb M, Lou Y (2015b) Prioritizing plant defence over growth through WRKY regulation facilitates infestation by non-target herbivores. Elife 54:e4805

Li Z, An XK, Liu YD, Hou ML (2016) Transcriptomic and expression analysis of the salivary glands in white-backed planthoppers, Sogatella furcifera. PLoS One 11:e159393

Li J, Liu X, Wang Q, Huangfu J, Schuman MC, Lou Y (2019) A group D MAPK protects plants from autotoxicity by suppressing herbivore-induced defense signaling. Plant Physiol 179:1386-1401

Ling B, Dong H, Zhang M, Xu D, Wang J (2007) Potential resistance of tricin in rice against brown planthopper Nilaparvata lugens (Stål). Acta Ecol Sin 27:1300-1306

Lison P, Rodrigo I, Conejero V (2006) A novel function for the cathepsin D inhibitor in tomato. Plant Physiol 142:13291339

Liu Z, Liu G, Sogawa K, Zhuang J, Chen S, Zheng K (2002) Mapping the gene Wbph2 in ARC10239 resistant to the whitebacked planthopper Sogatella furcifera in rice. Chin J Rice Sci 16:311-314

Liu C, Hao F, Hu J, Zhang W, Wan L, Zhu L, Tang H, He G (2010) Revealing different systems responses to brown planthopper infestation for pest susceptible and resistant rice plants with the combined metabonomic and gene-expression analysis. J Proteome Res 9:6774-6785

Liu Y, Wu H, Chen H, Liu Y, He J, Kang H, Sun Z, Pan G, Wang Q, Hu J, Zhou F, Zhou K, Zheng X, Ren Y, Chen L, Wang Y, Zhao Z, Lin Q, Wu F, Zhang X, Guo X, Cheng X, Jiang L, Wu C, Wang H, Wan J (2015) A gene cluster encoding lectin receptor kinases confers broad-spectrum and durable insect resistance in rice. Nat Biotechol 33:301-305

Liu SM, Li J, Zhu JQ, Wang XW, Wang CS, Liu SS, Chen XX, Li S (2016a) Transgenic plants expressing the AaIT/GNA fusion protein show increased resistance and toxicity to both chewing and sucking pests. Insect Sci 23:265-276

Liu Y, Chen L, Liu Y, Dai H, He J, Kang H, Pan G, Huang J, Qiu Z, Wang Q, Hu J, Liu L, Chen Y, Cheng X, Jiang L, Wan J (2016b) Marker assisted pyramiding of two brown planthopper resistance genes, $B P H 3$ and $B P H 27(\mathrm{t})$, into elite rice cultivars. Rice 9:27

Liu J, Du H, Ding X, Zhou Y, Xie P, Wu J (2017) Mechanisms of callose deposition in rice regulated by exogenous abscisic acid and its involvement in rice resistance to Nilaparvata lugens Stål (Hemiptera: Delphacidae). Pest Manag Sci 73: $2559-2568$

Liu X, Li J, Xu L, Wang Q, Lou Y (2018) Expressing OsMPK4 impairs plant growth but enhances the resistance of rice to the striped stem borer Chilo suppressalis. Int J Mol Sci 19:E1182 
Lu J, Li J, Ju H, Liu X, Erb M, Wang X, Lou Y (2014) Contrasting effects of ethylene biosynthesis on induced plant resistance against a chewing and a piercing-sucking herbivore in rice. Mol Plant 7:1670-1682

Lu J, Robert CA, Riemann M, Cosme M, Mène-Saffrané L, Massana J, Stout MJ, Lou Y, Gershenzon J, Erb M (2015) Induced jasmonate signaling leads to contrasting effects on root damage and herbivore performance. Plant Physiol 167: $1100-1116$

Lu HP, Luo T, Fu HW, Wang L, Tan YY, Huang JZ, Wang Q, Ye GY, Gatehouse AMR, Lou YG, Shu QY (2018) Resistance of rice to insect pests mediated by suppression of serotonin biosynthesis. Nat Plants 4:338-344

Lv W, Du B, Shangguan X, Zhao Y, Pan Y, Zhu L, He G (2014) $\mathrm{BAC}$ and RNA sequencing reveal the brown planthopper resistance gene $B P H 15$ in a recombination cold spot that mediates a unique defense mechanism. BMC Genomics 15: 674

Lyons R, Manner JM, Kazan K (2013) Jasmonate biosynthesis and signaling in monocots: a comparative overview. Plant Cell Rep 32:815-827

Ma F, Yang X, Shi Z, Miao X (2019) Novel crosstalk between ethylene- and jasmonic acid-pathway responses to a piercingsucking insect in rice. New Phytol. https://doi.org/10.1111 /nph.16111

Mao YB, Cai WJ, Wang JW, Hong GJ, Tao XY, Wang LJ, Huang YP, Chen XY (2007) Silencing a cotton bollworm P450 monooxygenase gene by plant-mediated RNAi impairs larval tolerance of gossypol. Nat Biotechnol 25:1307-1313

Matsumoto Y, Hattori M (2018) The green rice leafhopper, Nephotettix cincticeps (Hemiptera: Cicadellidae), salivary protein NcSP75 is a key effector for successful phloem ingestion. PLoS One 13:e0202492

Mattiacci L, Dicke M, Posthumus MA (1995) Beta-glucosidasean elicitor of herbivore-induced plant odor that attracts hostsearching parasitic wasps. Proc Natl Acad Sci U S A 92: 2036-2040

McConn M, Creelman RA, Bell E, Mullet JE, Browse J (1997) Jasmonate is essential for insect defense in Arabidopsis. Proc Natl Acad Sci U S A 94:5473-5477

Miles PW (1999) Aphid saliva. Biol Rev 74:41-85

Mohanty SK, Panda RS, Mohapatra SL, Nanda A, Behera L, Jena M, Sahu RK, Sahu SC, Mohapatra T (2017) Identification of novel quantitative trait loci associated with brown planthopper resistance in the rice landrace Salkathi. Euphytica 213:38

Mutti NS, Louis J, Pappan LK, Pappan K, Begum K, Chen MS, Park Y, Dittmer N, Marshall J, Reese JC, Reeck GR (2008) A protein from the salivary glands of the pea aphid, Acyrthosiphon pisum, is essential in feeding on a host plant. Proc Natl Acad Sci U S A 105:9965-9969

Myint KKM, Fujita D, Matsumura M, Sonoda T, Yoshimura A, Yasui $\mathrm{H}$ (2012) Mapping and pyramiding of two major genes for resistance to the brown planthopper (Nilaparvata lugens Stål) in the rice cultivar ADR52. Theor Appl Genet 124:495504

Nagadhara D, Ramesh S, Pasalu IC, Rao YK, Sarma NP, Reddy VD, Rao KV (2004) Transgenic rice plants expressing the snowdrop lectin gene (GNA) exhibit high level resistance to the whitebacked planthopper (Sogatella furcifera). Theor Appl Genet 109:1399-1405
Nemoto H, Ikeda R, Kaneda C (1989) New gene for resistance to brown planthopper, Nilaparvata lugens Stål, in rice. Jpn J Breed 39:23-28

Oerke EC (2006) Crop losses due to pests. J Agric Sci 144:31-43

Olsen KM, Wendel JF (2013) A bountiful harvest: genomic insights into crop domestication phenotypes. Annu Rev Plant Biol 64:47-70

Pan G, Liu Y, Ji L, Zhang X, He J, Huang J, Qiu Z, Liu D, Sun Z, Xu T, Liu L, Wang C, Jiang L, Cheng X, Wan J (2018) Brassinosteroids mediate susceptibility to brown planthopper by integrating with the salicylic acid and jasmonic acid pathways in rice. J Exp Bot 69:4433-4442

Pieterse CMJ, Van der Does D, Zamioudis C, Leon-Reyes A, Van Wees SCM (2012) Hormonal modulation of plant immunity. Annu Rev Cell Dev Biol 28:489-521

Prahalada GD, Shivakumar N, Lohithaswa HC, Sidde Gowda DK, Ramkumar G, Kim SR, Ramachandra C, Hittalmani S, Mohapatra T, Jena KK (2017) Identification and fine mapping of a new gene, $B P H 31$ conferring resistance to brown planthopper biotype 4 of India to improve rice, Oryza sativa L. Rice 10:41

Qi J, Zhou G, Yang L, Erb M, Lu Y, Sun X, Cheng J, Lou Y (2011) The chloroplast-localized phospholipases $\mathrm{D} \alpha 4$ and $\alpha 5$ regulate herbivore-induced direct and indirect defenses in rice. Plant Physiol 157:1987-1999

Qiu Y, Guo J, Jing S, Zhu L, He G (2010) High-resolution mapping of the brown planthopper resistance gene Bph6 in rice and characterizing its resistance in the 9311 and Nipponbare near isogenic backgrounds. Theor Appl Genet 121:1601-1611

Qiu Y, Guo J, Jing S, Zhu L, He G (2011) Development and characterization of japonica rice lines carrying the brown planthopper-resistance genes BPH12 and BPH6. Theor Appl Genet 124:485-494

Qiu Y, Guo J, Jing S, Zhu L, He G (2012) Development and characterization of japonica rice lines carrying the brown planthopper-resistance gene BPH12 and BPH6. Theor Appl Gene 124:485-494

Qiu Y, Guo J, Jing S, Zhu L, He G (2014) Fine mapping of the rice brown planthopper resistance gene $\mathrm{BPH} 7$ and characterization of its resistance in the 93-11 background. Euphyticaa 198:369-379

Rahman ML, Jiang W, Chu SH, Qiao Y, Ham TH, Woo MO, Lee J, Khanam MS, Chin JH, Jeung JU, Brar DS, Jena KK, Koh HJ (2009) High-resolution mapping of two brown planthopper resistance genes, Bph20(t) and Bph21(t), originating from Oryza minuta. Theor Appl Genet 119:12371246

Ram T, Deen R, Gautam SK, Ramesh K, Rao YK, Brar DS (2010) Identifcation of new genes for brown planthopper resistance in rice introgressed from $O$. glaberrima and $O$. minuta. Rice Genet Newsl 25:67-69

Ramesh K, Padmavathi G, Deen R, Pandey MK, Jhansi Lakshmi V, Bentur JS (2014) Whitebacked planthopper Sogatella furcifera (Horváth) (Homoptera: Delphacidae) resistance in rice variety Sinna Sivappu. Euphytica 200:139-148

Rao KV, Rathore KS, Hodges TK, Fu X, Stoger E, Sudhakar D, Williams S, Christou P, Bharathi M, Bown DP, Powell K, Spence J, Gatehouse AR, Gatehouse J (1998) Expression of snowdrop lectin (GNA) in transgenic rice plants confers resistance to rice brown planthopper. Plant J 15:469-477 
Rao YC, Dong GJ, Zeng DL, Hua J, Zeng LJ, Gao ZY, Zhang GH, Guo LB, Qian Q (2010) Genetic analysis of leaffolder resistance in rice. J Genet Genomics 37:325-331

Rao W, Zheng X, Liu B, Guo Q, Guo J, Wu Y, Shangguan X, Wang H, Wu D, Wang Z, Hu L, Xu C, Jiang W, Huang J, Shi $\mathrm{S}, \mathrm{He}$ G (2019) Secretome analysis and in planta expression of salivary proteins identify candidate effectors from the brown planthopper Nilaparvata lugens. Mol Plant-Microbe Interact 32:227-239

Ren J, Gao F, Wu X, Lu X, Zeng L, Lv J, Sun X, Luo H, Ren G (2016) Bph32, a novel gene encoding an unknown SCR domain-containing protein, confers resistance against the brown planthopper in rice. Sci Rep 6:37645

Renganayaki K, Fritz AK, Sadasivam S, Pammi S, Harrington SE, McCouch SR, Kumar SM, Reddy AS (2002) Mapping and progress toward map-based cloning of brown planthopper biotype-4 resistance gene introgressed from Oryza offcinalis into cultivated rice, $O$. sativa. Crop Sci 42:2112-2117

Rezaul Karim ANM, Pathak MD (1982) New genes for resistance to green leafhopper, Nephotettix virescens (distant) in rice Oryza sativa L. Crop Prot 1:483-490

Saka N, Tsuji T, Toyama T, Yano M, Izawa T, Sasaki T (2006) Development of cleaved amplified polymorphic sequence (CAPS) markers linked to a green rice leafhopper resistance gene, Grh3(t). Plant Breed 125:140-143

Sama VSAK, Rawat N, Sundaram RM, Himabindu K, Naik BS, Viratamath BC, Bentur JS (2014) A putative candidate for the recessive gall midge resistance gene gm3 in rice identified and validated. Theor Appl Genet 127:113-124

Sardesai N, Kumar A, Rajyashri KR, Nair S, Mohan M (2002) Identification and mapping of an AFLP marker liked to $\mathrm{Gm} 7$, a gall midge resistance gene and its conversion to a SCAR marker for its utility in marker aided selection in rice. Theor Appl Genet 105:691-698

Scott JG, Michel K, Bartholomay LC, Siegfried BD, Hunter WB, Smagghe G, Zhu KY, Douglas AE (2013) Towards the elements of successful insect RNAi. J Insect Physiol 59: $1212-1221$

Sebastian LS, Ikeda R, Huang N, Imbe T, Coffman WR, McCouch SR (1996) Molecular mapping of resistance to rice spherical virus and green leafhopper. Phytopathology 86:25-30

Seino Y, Suzuki Y, Sogawa K (1996) An ovicidal substance produced by rice plants in response to oviposition by the whitebacked planthopper, Sogatella furcifera (Horvá th) (Homoptera: Delphacidae). Appl Entomol Zool 31:467-473

Shangguan X, Zhang J, Liu B, Zhao Y, Wang H, Wang Z, Guo J, Rao W, Jing S, Guan W, Ma Y, Wu Y, Hu L, Chen R, Du B, Zhu L, Yu D, He G (2018) A mucin-like protein of planthopper is required for feeding and induces immunity response in plants. Plant Physiol 176:552-565

Sharma PN, Torii A, Takumi S, Mori N, Nakamura C (2004) Marker-assisted pyramiding of brown planthopper (Nilaparvata lugens Stål) resistance genes Bph1 and Bph2 on rice chromosome 12. Hereditas 136:39-43

Shinya T, Hojo Y, Desaki Y, Christeller JT, Okada K, Shibuya N, Galis I (2016) Modulation of plant defense responses to herbivores by simultaneous recognition of different herbivore-associated elicitors in rice. Sci Rep 6:32537

Shrivastava MN, Kumar A, Bhandarkar S, Shukla BC, Agrawal $\mathrm{KC}$ (2003) A new gene for resistance in rice to Asian rice gall midge (Orseolia oryzae wood Mason) biotype 1 population at Raipur, India. Euphytica 130:143-145

Sidhu GS, Khush GS (1978) Genetic analysis of brown planthopper resistance in twenty varieties of rice, Oryza sativa. Theor Appl Genet 53:199-203

Sidhu GS, Khush GS, Medrano FG (1979) A dominant gene in rice for resistance to white-backed planthopper and its relationship to other plant characteristics. Euphytica 28:227-232

Siwi BH, Khush GS (1977) New genes for resistance to green leafhopper in rice. Crop Sci 17:17-20

Strong DR, Lawton JH, Southwood TRE (1984) Insects on plants: community patterns and mechanisms. Harvard University Press, Cambridge

Sun X, Wu A, Tang K (2002) Transgenic rice lines with enhanced resistance to the small brown planthopper. Crop Prot 21:511514

Sun L, Su C, Wang C, Zhao H, Wan J (2005) Mapping of a major resistance gene to the brown planthopper in the rice cultivar Rathu Heenati. Breed Sci 55:39139-39136

Sun L, Wang C, Su C, Liu Y, Zhai H, Wan J (2006) Mapping and marker-assisted selection of a brown planthopper resistance gene bph 2 in rice (Oryza sativa L.). Acta Genet Sin 33:717273

Sun Y, Zhang YJ, Cao GC, Gu SH, Wu KM, Gao X, Yuan YG (2010) Rice gene expression profiles responding to larval feeding of the striped stem borer at the 1 st to 2 nd instar stage. Insect Sci 18:273-281

Sun Z, Liu Y, Xiao S, Hu J, Pan G, He J, Xu T, Huang J, Qiu Z, Fan D, Zhang L, Liu L, Jiang L, Cheng X, Zhao H, Wan J (2017) Identification of quantitative trait loci for resistance to rice black-streaked dwarf virus disease and small brown planthopper in rice. Mol Breed 37:72

Tabashnik BE, Brevault T, Carriere Y (2013) Insect resistance to Bt crops: lessons from the first billion acres. Nat Biotechnol 31:510-521

Tamura K, Fukuta Y, Hirae M, Oya S, Ashikawa I, Yagi T (2004) RFLP mapping of a new resistance gene for green rice leafhopper in Kanto PL10. Rice Genet Newslett 21:62-64

Tamura Y, Hattori M, Yoshioka H, Yoshioka M, Takahashi A, Wu J, Sentoku N, Yasui H (2014) Map-based cloning and characterization of a brown planthopper resistance gene $\mathrm{BPH} 26$ from Oryza sativa L. ssp. indica cultivar ADR52. Sci Rep 4: 5872

Tan G, Weng Q, Ren X, Huang Z, Zhu L, He G (2004) Two whitebacked planthopper resistance genes in rice share the same loci with those for brown planthopper resistance. Heredity 92:212-217

The 3,000 rice genomes project (2014) 3K RGP. Gigascience 3:7

Tong X, Qi J, Zhu X, Mao B, Zeng L, Wang B, Li Q, Zhou G, Xu X, Lou Y, He Z (2012) The rice hydroperoxide lyase OSHPL3 functions in defense responses by modulating the oxylipin pathway. Plant J 71:763-775

Wan B, Zha Z, Li J, Xia M, Du X, Lin Y, Yin D (2014) Development of elite rice restorer lines in the genetic background of R022 possessing tolerance to brown planthopper, stem borer, leaf folder and herbicide through marker assisted breeding. Euphytica 195:129-142

Wang X, He R, He G (2005) Construction of suppression subtractive hybridization libraries and identification of brown planthopper induced genes. J Plant Physiol 162:1254-1262 
Wang H, Hao J, Chen X, Hao Z, Wang X, Lou Y, Peng Y, Guo Z (2007) Overexpression of rice WRKY89 enhances ultraviolet $\mathrm{B}$ tolerance and disease resistance in rice plants. Plant Mol Biol 65:799-815

Wang Y, Wang X, Yuan H, Chen R, Zhu L, He R, He G (2008) Responses of two contrasting genotypes of rice to brown planthopper. Mol Plant-Microbe Interact 21:122-132

Wang Y, Guo H, Li H, Zhang H, Miao X (2012) Identification of transcription factors potential related to brown planthopper resistance in rice via microarray expression profiling. BMC Genomics 13:687

Wang Q, Li J, Hu L, Zhang T, Lou Y (2013a) OsMPK3 positively regulates the JA signaling pathway and plant resistance to a chewing herbivore in rice. Plant Cell Rep 32:1075-1084

Wang Q, Liu Y, Hu J, Zhang Y, Xie K, Wang B, Tuyen le Q, Song Z, Wu H, Liu Y, Jiang L, Liu S, Cheng X, Wang C, Zhai H, Wan J (2013b) Detection of quantitative trait loci (QTLs) for resistances to small brown planthopper and rice stripe virus in rice using recombinant inbred lines. Int J Mol Sci 14:84068421

Wang B, Zhou G, Xin Z, Ji R, Lou Y (2015a) (Z)-3-hexenal, one of the green leaf volatiles, increases susceptibility of rice to the white-backed planthopper Sogatella furcifera. Plant Mol Biol Rep 33:377-387

Wang Y, Cao L, Zhang Y, Cao C, Liu F, Huang F, Qiu Y, Li R, Lou $\mathrm{X}$ (2015b) Map-based cloning and characterization of $\mathrm{BPH} 29$, a B3 domain-containing recessive gene conferring brown planthopper resistance in rice. J Exp Bot 66:60356045

Wang H, Ye S, Mou T (2016) Molecular breeding of rice restorer lines and hybrids for brown planthopper $(\mathrm{BPH})$ resistance using the Bph14 and Bph15 genes. Rice 9:53

Wang Y, Jiang W, Liu H, Zeng Y, Du B, Zhu L, He G, Chen R (2017) Marker assisted pyramiding of Bph6 and Bph9 into elite restorer line 93-11 and development of functional marker for Bph9. Rice 10:51

Wang H, Shi S, Guo Q, Nie L, Du B, Chen R, Zhu L, He G (2018a) High-resolution mapping of a gene conferring strong antibiosis to brown planthopper and developing resistant near-isogenic lines in 9311 background. Mol Breed 38:107

Wang X, Liu Q, Meissle M, Peng Y, Wu K, Romeis J, Li Y (2018b) Bt rice could provide ecological resistance against nontarget planthoppers. Plant Biotechnol J 16:1748-1755

Wang M, Yang D, Ma F, Zhu M, Shi Z, Miao X (2019) OsHLH61OsbHLH96 influences rice defense to brown planthopper through regulating the pathogen-related genes. Rice 12:9

Wari D, Kabir MA, Mujiono K, Hojo Y, Shinya T, Tani A, Nakatani H, Galis I (2019) Honeydew-associated microbes elicit defense responses against brown planthopper in rice. J Exp Bot 70:1683-1696

Wei Z, Hu W, Lin QS, Cheng XY, Tong MJ, Zhu LL, Chen RZ, He GC (2009) Understanding rice plant resistance to the brown planthopper (Nilaparvata lugens): a proteomic approach. Proteomics 9:2798-2808

Wu CF, Khush GS (1985) A new dominant gene for resistance to whitebacked planthopper in rice. Crop Sci 25:505-509

Wu H, Liu Y, He J, Liu Y, Jiang L, Liu L, Wang C, Cheng X, Wan J (2014) Fine mapping of brown planthopper (Nilaparvata lugens Stål) resistance gene Bph28(t) in rice (Oryza sativa L.). Mol Breed 33:909-918
Wu Y, Lv W, Hu L, Rao W, Zeng Y, Zhu L, He Y, He G (2017) Identification and analysis of brown planthopper-responsive microRNAs in resistant and susceptible rice plants. Sci Rep 7:8712

Xiao Y, Wang Q, Erb M, Turlings TC, Ge L, Hu L, Li J, Han X, Zhang T, Lu J, Zhang G, Lou Y (2012) Specific herbivoreinduced volatiles defend plants and determine insect community composition in the field. Ecol Lett 15:1130-1139

Xiao C, Hu J, Ao YT, Cheng MX, Gao GJ, Zhang QL, He GC, He YQ (2016) Development and evaluation of near-isogenic lines for brown planthopper resistance in rice cv. 9311. Sci Rep 6:38159

$\mathrm{Xu} \mathrm{C}$, Cheng J, Lin H, Lin C, Gao J, Shen Z (2018a) Characterization of transgenic rice expressing fusion protein Cry1Ab/Vip3A for insect resistance. Sci Rep 8:15788

Xu T, Liu Y, Zhang L, Liu L, Wang C, Hu J, Sun Z, Pan G, Xiao S, He J, Huang J, Qiu Z, Fan D, Jiang L, Cheng X, Zhai H, Wan J (2018b) Mapping of quantitative trait loci associated with rice black-streaked dwarf virus disease and its insect vector in rice (Oryza sativa L.). Plant Breed 137:698-705

Yamane H (2013) Biosynthesis of phytoalexins and regulatory mechanisms of it in rice. Biosci Biotechnol Biochem 77: 1141-1148

Yamasaki M, Yoshimura A, Yasui H (2003) Genetic basis of ovicidal response to whitebacked planthopper (Sogatella furcifera Horváth) in rice (Oryza sativa L.). Mol Breed 12: 133-143

Yang L, Zhang W (2016) Genetic and biochemical mechanisms of rice resistance planthopper. Plant Cell Rep 35:1559-1572

Yang H, You A, Yang Z, Zhang F, He R, Zhu L, He G (2004) High-resolution genetic mapping at the Bph15 locus for brown planthopper resistance in rice (Oryza sativa L.). Theor Appl Genet 110:182-191

Yang L, Li RB, Li YR, Huang FK, Chen YZ, Huang SS, Huang LF, Liu C, Ma ZF, Huang DH, Jiang JJ (2012) Genetic mapping of bph20(t) and bph21(t) loci conferring brown planthopper resistance to Nilaparvata lugens Stål in rice (Oryza sativa L.). Euphytica 183:161-171

Yang Y, Xu J, Leng Y, Xiong G, Hu J, Zhang G, Huang L, Wang L, Guo L, Li J, Chen F, Qian Q, Zeng D (2014) Quantitative trait loci identification, fine mapping and gene expression profiling for ovicidal response to whitebacked planthopper (Sogatella furcifera Horváth) in rice (Oryza sativa L.). BMC Plant Biol 14:145

Yang Y, Li L, Qu LJ (2016) Plant mediator complex and its critical functions in transcription regulation. J Integr Plant Biol 58: 106-118

Yang L, Li A, Zhang W (2019) Current understanding of the molecular players involved in resistance to rice planthoppers. Pest Manag Sci 75:2566-2574

Yasala AK, Rawat N, Sama VSAK, Himabindu K, Sundaram RM, Bentur JS (2012) In silico analysis for gene content in rice genomic regions mapped for the gall midge resistance genes. Plant Omics J 5:405-413

Ye M, Lou SM, Xie JF, Li YF, Xu T, Liu Y, Song YY, ZhuSalzman K, Zeng RS (2012) Silencing COI1 in rice increases susceptibility to chewing insects and impairs inducible defense. PLoS One 7:e36214

Yuan H, Chen X, Zhu L, He G (2005) Identification of genes responsive to brown planthopper Nilaparvata lugens Stål 
(Homoptera: Delphacidae) feeding in rice. Planta 221:105112

Zha W, Peng X, Chen R, Du B, He G (2011) Knockdown of midgut genes by dsRNA-transgenic plant-mediated RNA interference in the hemipteran insect Nilaparvata lugens. PLoS One 6:e20504

Zhang Q (2007) Strategies for developing green super Rice. Proc Natl Acad Sci U S A 104:16402-16409

Zhang G, Zhang W, Lian B, Gu L, Zhou Q, Liu T (1999) Insecticidal effects of extracts from two rice varieties to brown planthopper, Nilaparvata lugens. J Chem Ecol 25: 1843-1853

Zhang F, Zhu L, He G (2004) Differential gene expression in response to brown planthopper feeding in rice. J Plant Physiol 161:53-62

Zhang W, Dong Y, Yang L, Ma B, Ma R, Huang F, Wang C, Hu H, Li C, Yan C, Chen J (2014) Small brown planthopper resistance loci in wild rice (Oryza officinalis). Mol Gen Genomics 289:373-382

Zhang J, Luo T, Wang W, Cao T, Li R, Lou Y (2017) Silencing OSSLR1 enhances the resistance of rice to the brown planthopper Nilaparvata lugens. Plant Cell Environ 40: 2147-2159

Zhang J, Li Y, Guo J, Du B, He G, Zhang J, Chen R, Li J (2018) Lipid profiles reveal different responses to brown planthopper infestation for pest susceptible and resistant rice plants. Metabolomics 14:120

Zhao C, Escalante LN, Chen H, Benatti TR, Qu J, Chellapilla S, Waterhouse RM, Wheeler D, Andersson MN, Bao R, Batterton M, Behura SK, Blankenburg KP, Caragea D, Carolan JC, Coyle M, El-Bouhssini M, Francisco L, Friedrich M, Gill N, Grace T, Grimmelikhuijzen CJ, Han Y, Hauser F, Herndon N, Holder M, Ioannidis P, Jackson L, Javaid M, Jhangiani SN, Johnson AJ, Kalra D, Korchina V, Kovar CL, Lara F, Lee SL, Liu X, Löfstedt C, Mata R,
Mathew T, Muzny DM, Nagar S, Nazareth LV, Okwuonu G, Ongeri F, Perales L, Peterson BF, Pu LL, Robertson HM, Schemerhorn BJ, Scherer SE, Shreve JT, Simmons D, Subramanyam S, Thornton RL, Xue K, Weissenberger GM, Williams CE, Worley KC, Zhu D, Zhu Y, Harris MO, Shukle RH, Werren JH, Zdobnov EM, Chen MS, Brown S, Stuart JJ, Richards S (2015) A massive expansion of effector genes underlies gall-formation in the wheat pest Mayetiola destructor. Curr Biol 25:613-620

Zhao Y, Huang J, Wang Z, Jing S, Wang Y, Ouyang Y, Cai B, Xin XF, Liu X, Zhang C, Pan Y, Ma R, Li Q, Jiang W, Zeng Y, Shangguan X, Wang H, Du B, Zhu L, Xu X, Feng YQ, He SY, Chen R, Zhang Q, He G (2016) Allelic diversity in an NLR gene $B P H 9$ enables rice to combat planthopper variation. Proc Natl Acad Sci U S A 113:12850-12855

Zhou G, Qi J, Ren N, Cheng J, Erb M, Mao B, Lou Y (2009) Silencing $O s H I-L O X$ makes rice more susceptible to chewing herbivores, but enhances resistance to a phloem feeder. Plant J 60:638-648

Zhou G, Wang X, Yan F, Wang X, Li R, Cheng J, Lou Y (2011) Genome-wide transcriptional changes and defence-related chemical profiling of rice in response to infestation by the rice striped stem bore Chilo suppressalis. Physiol Plant 143: $21-40$

Zhou G, Ren N, Qi J, Lu J, Xiang C, Ju H, Cheng J, Lou Y (2014) The 9-lipoxygenase Osr9-LOXI interacts with the 13lipoxygenase-mediated pathway to regulate resistance to chewing and piercing-sucking herbivores in rice. Physiol Plant 152:59-69

Publisher's note Springer Nature remains neutral with regard to jurisdictional claims in published maps and institutional affiliations. 